Review

\title{
Synthesizing Vulnerability, Risk, Resilience, and Sustainability into VRRSability for Improving Geoinformation Decision Support Evaluations
}

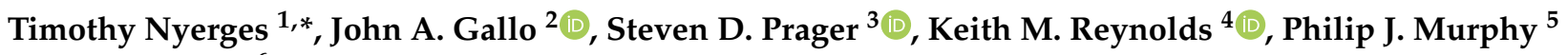 \\ and WenWen $\mathrm{Li}^{6}$ \\ GeoInfo LLC and Department of Geography, University of Washington, Seattle, WA 98195, USA \\ Conservation Biology Institute, Corvallis, OR 97333, USA; john.gallo@consbio.org \\ International Center for Tropical Agriculture, Cali 763357, Colombia; s.prager@cgiar.org \\ US Department of Agriculture, Forest Service Research, Corvallis, OR 97331, USA; keith.reynolds2@usda.gov \\ Info Harvest, Inc., Seattle, WA 98165, USA; philip.murphy@infoharvest.com \\ 6 School of Geographical Science and Urban Planning, Arizona State University, Tempe, AZ 85287-5302, USA; \\ wenwen@asu.edu \\ * Correspondence: nyerges@uw.edu or tim.nyerges@gmail.com
}

check for

updates

Citation: Nyerges, T.; Gallo, J.A.; Prager, S.D.; Reynolds, K.M.; Murphy, P.J.; Li, W. Synthesizing Vulnerability, Risk, Resilience, and Sustainability into VRRSability for Improving Geoinformation Decision Support Evaluations. ISPRS Int. J. Geo-Inf. 2021, 10, 179. https://doi.org/ 10.3390/ijgi10030179

Academic Editors: Ozgun Akcay and Wolfgang Kainz

Received: 9 October 2020

Accepted: 15 March 2021

Published: 18 March 2021

Publisher's Note: MDPI stays neutral with regard to jurisdictional claims in published maps and institutional affiliations.

Copyright: (C) 2021 by the authors. Licensee MDPI, Basel, Switzerland. This article is an open access article distributed under the terms and conditions of the Creative Commons Attribution (CC BY) license (https:// creativecommons.org/licenses/by/ $4.0 /)$

Abstract: This paper synthesizes vulnerability, risk, resilience, and sustainability (VRRS) in a way that can be used for decision evaluations about sustainable systems, whether such systems are called coupled natural-human systems, social-ecological systems, coupled human-environment systems, and/or hazards influencing global environmental change, all considered geospatial open systems. Evaluations of V-R-R-S as separate concepts for complex decision problems are important, but more insightful when synthesized for improving integrated decision priorities based on trade-offs of V-R-R-S objectives. A synthesis concept, called VRRSability, provides an overarching perspective that elucidates Tier 2 of a previously developed four-tier framework for organizing measurement-informed ontology and epistemology for sustainability information representation (MOESIR). The new synthesis deepens the MOESIR framework to address VRRSability information representation and clarifies the Tier 2 layer of abstraction. This VRRSability synthesis, composed of 13 components (several with sub-components), offers a controlled vocabulary as the basis of a conceptual framework for organizing workflow assessment and intervention strategies as part of geoinformation decision support software. Researchers, practitioners, and machine learning algorithms can use the vocabulary results for characterizing functional performance relationships between elements of geospatial open systems and the computing technology systems used for evaluating them within a context of complex sustainable systems.

Keywords: decision support software; open systems; sustainable systems; human-environment systems; ontology; epistemology

\section{Introduction}

This research works toward implementing software that helps humanity and technology attain a more sustainable relationship with life on Earth. It deepens a software development framework that has four tiers, and three levels for each tier. One of those 12 tier and level combinations is a conceptual framework for sustainability evaluation [1]. In detailing this framework using a computer software design perspective, we found that the dynamics of evaluation would be considerably enhanced if we expanded the scope to include the related concepts of vulnerability, risk, and resilience. Hence, this new tier-level framework becomes a conceptual framework for vulnerability, risk, resilience, and sustainability, or a new overarching concept which we call VRRSability. The details of this framing account for the sub-components of VRRSability and how they relate to each other, all with an aim for making these complex concepts and relationships understandable to not only humans, but 
machine learning algorithms as well. These specifications of VRRSability are meant to not only further the aforementioned framework, but also any geospatial open system.

Characterizing vulnerability, risk, resilience, and/or sustainability of regional communities as systems-whether they are called coupled natural-human systems, socialecological systems, coupled human-environment systems, or hazards influencing global environmental change, in computer-compatible form - is of growing interest to both research and communities of practice in decision support [1-5]. For example, land use/land cover, water quantity, and water quality sub-systems exist within urban-regional systems as a combination of natural and built interconnected infrastructure systems, and are in need of comprehensive and robust management due to increasing complexities of spacetime interactions among nature, humans, and technology [6-8]. These natural and built interconnected infrastructures are complex systems because they exist as geospatial open systems, whether considered sustainable or not. Many open systems that support health and well-being as sustainable systems are difficult to manage because no single organization has responsibility for all aspects of coupled systems; decisions intended to affect one dimension of a particular system may have unintended consequences in other dimensions. Consequently, surprises might emerge from either natural or human influences, thus making adaptive management particularly important for managing system behavior. Complete knowledge of complex, open, and sustainable systems behavior is difficult to articulate, if not impossible to track. As such, organizations responsible for addressing and managing complex systems behavior are seeking better ways to understand and improve vulnerability, risk, resilience and sustainability evaluation of system behavior [9-12].

Motivation for this research on evaluating human-environment relations stems from the many inadequate attempts at synthesizing among the four concepts of vulnerability, risk, resilience and sustainability (wherein VRRS is used when all four together is meant, and V-R-R-S is used when each of the four is meant). This effort synthesizes all four concepts within a single conceptual characterization called VRRSability to aid in unpacking linkages and synergies among the concepts. The synthesis reported in this paper is limited to an enumeration of sub-concepts contained within V-R-R-S without calling out, at least explicitly, the conceptual relations among the sub-concepts. Since a synthesis of conceptual relations for the full conceptual framework requires additional research, they are to be reported in a follow-on publication. Nonetheless, this enumerated list of concepts and sub-concepts framed into components represents a first step in developing an operational computing framework of VRRSability components for improving the potential for assessment and intervention of complex systems within geoinformation decision support. The overall end goal of this effort is implementation as open systems software components. Such software development will facilitate deliberative evaluations by regional stakeholder communities using participatory decision approaches which continue to stymie large-scale collaborative decision situations [13]. Too many stakeholder discussions seem to flow past one another because of the inability to share insights given the complexity of overlaps and underlaps in meaning of terms even when we focus on a single human-environment relation within a substantive domain. Integrated software environments that enable realtime comparisons of VRRSability, and constituent components therein, might significantly ameliorate these challenges.

A robust and operational synthesis-one that is both more comprehensive and simpler than the sum of the V-R-R-S concept parts-has yet to be provided in literature. This research has a goal to elucidate VRRSability as an overarching concept. No previous research has directly suggested the need for an overarching concept, although it is clear that many research results substantiate this idea, and many of those research contributions are highlighted in this paper. The overarching term arose only after we thought we could offer 'sustainability' as the overarching term since it is conventionally more general than the others, e.g., the phrase sustainability science, as it has developed over the past two decades, has tried to incorporate the other terms. It was not to be because each component of the V-R-R-S concept has its use and value; thus, none of the four wholly replace the others. 
The value of a four-prong synthesis of V-R-R-S into VRRSability offers an opportunity to make operational how each V-R-R-S concept is related to the others, moving from conceptualization in meaning into a logical design of a programming language and its physical design implementation in software, which is a common three-level information abstraction approach in software development [1]. The details of operational design (level 2) and implementation in software (level 3) are beyond the scope of this paper, as this paper focuses on the conceptualization level of information abstraction.

This paper proceeds in Section 2 by situating a VRRSability synthesis as part of a broader research framework, drawing on a software abstraction approach to tiered software architecture. In Section 3, we outline the methods used for analysis of concepts and subconcepts, treating VRRS as individual concepts before we treat all concepts together in a synthesis. We first present a content analysis of definitions which is followed by a more extensive and deeper investigation of research literature from which we enumerate VRRS components. In Section 4, we discuss insights emerging from the literature review synthesis. Section 5 contains conclusions about the synthesis results and next steps for research.

\section{Situating a VRRSability Synthesis}

Situating a domain for software development enhances the opportunity for operational success. Consequently, to help focus the VRRSability synthesis, an important thread within research about the high value of widely pervasive complex social-ecological and interconnected infrastructure systems involves characterizing functional performance of such systems $[12,14,15]$. A function of many complex systems concerns provision of one or more fundamental services to support health and well-being, e.g., water distribution across a landscape through green infrastructure (re)development. A functional performance approach takes a step past a condition-based approach such that characteristics of conditions support delivery of a functional service level [16]. Functional service has become so important that some researchers characterize functional performance in terms of critical functionality $[8,17]$, wherein the functional performance of certain elements within systems, and certain systems within interconnected systems, are more important to delivery of service than other functions. Functionality, as a term, takes on a 'nominal' measurement, i.e., it is recognized as being important to meaning, but herein we describe function in terms of performance at an ordinal scale, i.e., as a rank measurement to indicate that 'levels of performance' are indeed important when considering functionality.

Many natural capital systems provide functional services in the form of ecosystem services that can be evaluated for their importance to health and well-being [18]. The Washington State Department of Ecology conducted watershed characterizations as assessments of water resource functional performance for sub-systems (land use/land cover, water flow, water quality, and habitat quality) based on drainage analysis units within subwatersheds [19]. Freshwater flow is the critical sub-system of the overall water resource system that includes a water quality and habitat service; however, all sub-systems are important to the functional performance, and labeling some as more critical should be a result of understanding the importance of co-dependencies. Consequently, herein, we use the term 'functional performance' of services because it is more general and applicable to all elements, sub-systems, and systems, while still recognizing that some portions are likely to be more salient under various circumstances. Integrated methodologies for characterizing functional performance gaps within systems are becoming increasingly useful for understanding system performance more broadly $[20,21]$. Synthesizing across V-R-R-S simplifies and focuses efforts for evaluation of functional performance as part of decision support [5,22], using a blend of ontology-oriented and epistemology-oriented geographic (geospatial) information science.

Ontology-oriented information science and technology research attempts to create comprehensive and robust foundations for knowledge-based information representations based on shared insight about information engineering specifications [23]. Ontology research within geographic information (representation) science about shared understanding 
of data measurement representations emphasizes such detailed specifications [24]. In decision support research, many of the ontological representations not only involve data, but models and workflows as well [25]. As such, linked with ontology, formalizing approaches for using geospatial information representations involves epistemology [26]. The Oxford English Dictionary defines epistemology as "The theory of knowledge and understanding, esp. with regard to its methods, validity, and scope." Research about methods within geographic information science has received considerable attention in terms of data collection, manipulation, analysis, and visualization methods; for example, consider any geographic information science handbook. However, a theoretical foundation for geographic information science methods that focus on epistemology were under-investigated as of 2009 [26], and gained somewhat more interest within volunteer geographic information science over time [27], but has yet to achieve a level of exposure needed to advance workflow software that can enhance workflow designs. Further developments in workflow software, e.g., as needed to advance geodesign workflow dynamics [28], will likely encourage computer-supported investigations into geoinformation epistemology.

The blending of ontology and epistemology facilitates both broadening and deepening of knowledge-based geospatial decision support software design, but at the same time simplifies it, for addressing decision problems in complex systems. Previous research outlined four tiers of information abstraction (two tiers of ontology and two tiers of epistemology) constituting a start to a sustainability information representation theory [1] motivated in part by an ontological abstraction approach to geospatial information [24]. Those four tiers compose a measurement-informed ontology and epistemology for sustainability information representation (MOESIR) framework [1], depicted in Figure 1. The framework is meant to articulate and enable a computing approach for characterizing complex systems sustainability, now extended to include vulnerability, risk, and resilience, based on a strategy of information gain both within and across tiers. Tier 1 provides the spatial-temporal-attribute building blocks of a system representation, e.g., a complex system uses nodes and links to characterize a green infrastructure network, wherein the nodes can be points, polygons and/or rasters as convenient to data structure development. As in much of the more recent research in geographic information science, this ontology research is meant to offer sufficient detail for computer implementation of the elements and relations among them using a systems approach to articulation; detailing concepts and relations is the most effective way to making them operational $[24,26,28]$. Tier 2 layers vulnerability, risk, resilience, and sustainability considerations onto (some might say into) the system representation, wherein the concepts emerge as either supporting or complementary concepts to one another, but were not operationally differentiated in previous research. As such, Tier 2 provides an evaluative component for the complex system representation. However, how we evaluate using vulnerability, risk, resilience and/or sustainability could be at odds with each other. As such, a comprehensive synthesis of these concepts is needed to compute them all in relation to each other. Tier 3 layers a decision support workflow approach onto the VRRS considerations, noting that geodesign provides a broad and deep approach, but currently addresses vulnerability only [28]. Workflows can be of very different characters. In terms of the Oxford English dictionary, epistemology is defined in terms of methodology, as in a sequence of steps to carry out a computation. How we sequence steps depends on what concepts (Tier 2) we are computing, and for what complex systems phenomena (Tier 1) these are being computed. Tier 4 layers an application purpose onto workflow methods, wherein goals, objectives, and metrics for functional performance of systems set the focus. At Tier 4, people might establish goals, objectives and criteria for each V-R-R-S component in a VRRSability assessment that is used to formulate potential design options for changing a system; together assessment (representation, process, and evaluation) and intervention (options design, impacts, choices) are the foundation of geodesign decision support [28]. Together the four tiers, each available for inspection by software users, offer transparency in complex decision making situations. The complexity of this tiering can be clarified and addressed by treating each of the tiers in terms of their conceptual, logical and physical 
design instantiations (Figure 1). One should conceptualize ideas clearly before logically specifying a design approach and physically implementing a software system; these three steps often being considered a basis for robust software development.

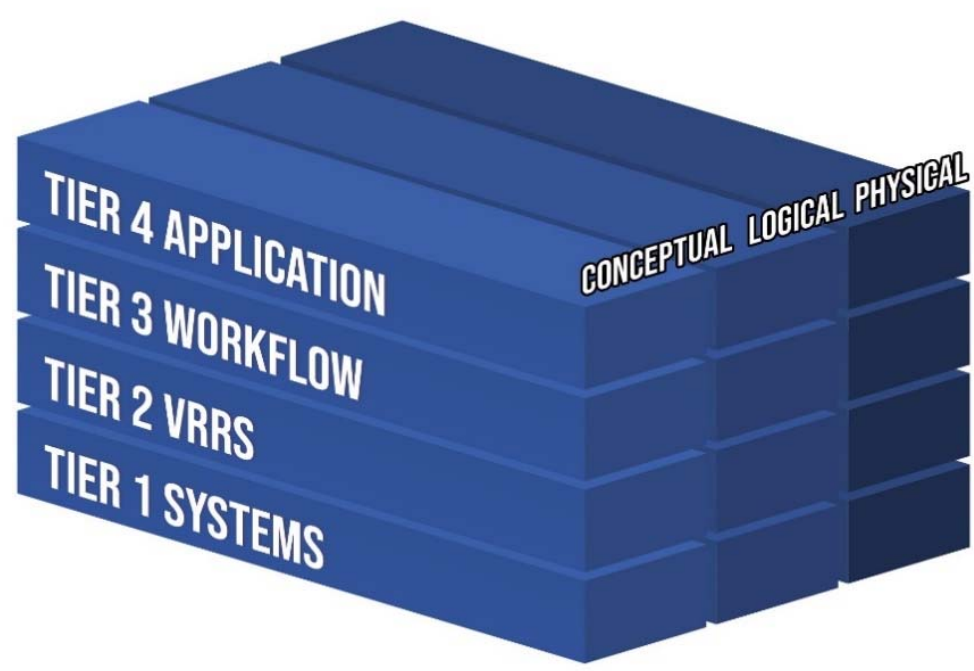

Figure 1. MOESIR four-tier ontological and epistemological framework for decision support systems implementation abstraction. Four tiers of software systems components are each expressed in terms of conceptual, logical, and physical levels of abstraction for comprehensive elucidation. This research focuses on the Tier 2 conceptual level.

This paper provides a VRRSability conceptual synthesis at Tier 2. Further research would then compose a logical design as a VRRSability data model (data constructs, operations, and constraints), articulating and detailing components sufficiently for writing software. A software implementation configures a physical design, as software environments (e.g., programming languages) use data structure types and methods for creating operational instances of conceptual and logical levels. Clarifying VRRS concepts to a point where they are suitable for computer implementation within decision support models is a long-term goal of this research. Representation, process dynamics, and evaluation modeling constitute the three workflow steps within a geodesign assessment [29]; geodesign being defined generally as 'changing geography by design' [29]. As such, functional performance evaluation constitutes the third step of assessment. A geodesign workflow process conventionally includes vulnerability (only) as part of assessment. Nyerges et al. [28] followed a geodesign workflow to assess sustainable development of urban watersheds, addressing vulnerability and development of a complex community system composed of the ten sub-systems within a comprehensive plan as an application at Tier 4. Because the Tier 2 method of vulnerability assessment does not include risk and resilience, and measured levels of sustainable functional performance (aka sustainability) are absent; these limitations provided further motivation for this research.

This research adds risk, resilience and sustainability to the evaluation approach of geodesign [29], while offering broad and deep insight about functional performance in terms of VRRSability. Subsequently, evaluation is the basis of understanding a (degree or magnitude of) need (or not as appropriate) for improvement intervention. Design change modeling, impact modeling, and decision modeling are the three steps of geodesign workflow constituting an intervention process that follows from assessment. As such, intervention makes use of evaluations as a basis for understanding trade-offs among intervention actions. Decision support methods often implement evaluation using trade-offs among multiple criteria [30,31]; e.g., describing functional performance of various interconnected systems, while considering option trade-offs using these criteria [13]. We need to know whether trade-offs of functional performance are both present and relevant, given a particular specification of VRRS goals, objectives and corresponding performance criteria 
metrics. Implementing decision trade-offs in an operational manner can simplify complex decision making about coupled human-environment systems [5]. Decision support trade-offs likely differ depending on the individual V-R-R-S evaluations. It is clear that all of these matter in some way when addressing a phenomenon as part of a coupled human-environment system. A framework that embraces these system complexities in terms of clear articulation of V-R-R-S trade-offs in relation to one another can help improve software design effectiveness and solutions to complex decision problems.

\section{Analysis and Synthesis Methods for Enumerating VRRSability Components}

In this section, we present the methods used for analysis and synthesis. We first outline the emergence of the four V-R-R-S concepts, then use those insights about relationships to unpack and report on two types of content analyses efforts to extract sub-concepts from literature from which two levels of synthesis are drawn. One synthesis is based on glossary definitions (one might say ontological terms in practice) and a more comprehensive synthesis is based on literature review (one might say ontological terms in theory). Providing a brief overview of the emergence of concepts provides a general idea about how concepts are related. That general idea frames the overall approach for a more detailed content analysis of concepts. The first content analysis adopts 'credible' definitions of VRRS concepts appearing in glossaries published by US Federal and international organizations, and synthesizes sub-concept phrases into an initial set of conceptual components. Credible definitions, and the documents from which they are drawn, are those that are widely-published and accepted reports in both theory and practice research milieus, but predominantly practice among national and international agencies. The second content analysis uses a review of several dozen articles that treat VRRS concepts in combinations. Articles with combinations of two, three and/or four concepts were sought specifically because these offer insights readily useful for concept syntheses. From the latter content analysis, we synthesize an additional list of conceptual components to identify and refine the content of a VRRSability synthesis.

\subsection{Emergence of $V-R-R-S$ Concepts and Framing the State of $V-R-R-S$ Theory}

V-R-R-S concepts emerged in literature at different times for different reasons, each being important, but none being a substitute for the other. Herein, we briefly describe an emergence of concepts, as full histories and etymologies are the goals of research published elsewhere as cited below and beyond the scope of this paper. We provide insights about emergence of concepts to each V-R-R-S component in turn to enable readers to better understand how concepts are juxtaposed in decades old research, the state of V-R-R-S theory as of this research, and observe how there is an opportunity for syntheses among them which is a first step in creating VRRSability theory. To explore emergence of concepts, we used a Scholar.Google.com search of each of the vulnerability, risk, resilience, and sustainability concepts and then added the appropriate V-R-R-S qualifier to theory to obtain any commonly cited references. It should be noted that a Google Scholar search highlights more popular phrases across web pages as opposed to a single accurate key phrase containing the search keywords in more recent publications. Nonetheless, the results are telling about the state of literature.

In regards to vulnerability, Turner et al. [2], like many other researchers, credit White [32] with initiating vulnerability analysis in natural hazards research, continue to synthesize insight from among several researchers across decades from research about vulnerability, resilience, and sustainability into a framework for vulnerability analysis within sustainability science research. They describe how vulnerability started as part of the risk paradigm, and now embraces the concept of resilience as part of vulnerability. They describe how vulnerability analysis is a part of sustainability, drawing together insights about the spatial and temporal scales involved in further development of sustainability science. Cutter et al. [10] examine the concepts of vulnerability and resilience, showing that some researchers see each as a subset of the other, and concluding that both are equally 
important in themselves, but share a common core about susceptibility of threat (disturbance) to receptors. In terms of the rigor of a 'vulnerability theory', the phrase appears in socio-political contexts as an articulation of how people are disadvantaged, arguing to replace equality before the law with 'equity' before the law [33]. The use of the phrase 'vulnerability theory' in the above published research is based on legal interpretations, with a basis in the observed human condition as opposed to systematic hypothesis testing. As such, from the authors' knowledge, no researchers have used the phrase 'vulnerability theory' because of a pervasive absence of systematic hypothesis testing.

In regards to risk, Aven [34,35] cites several researchers who define risk in various ways, and provides a brief history of its concept development. He compares perspectives on risk and concludes that a key issue to all of the definitions is that risk is fundamentally about probability (uncertainty) of harm in a situation, regardless if the situation is simple (e.g., as in dealing with a threat to a single receptor) or complex (e.g., as in dealing with threats to multiple receptors in a situation). Aven's [34] synthesis of vulnerability, risk, and resilience was developed in response to Haimes' $[3,4]$ systems-based approach to risk and resilience. Aven [34] contends that a systems-based approach is not needed to characterize vulnerability, risk and resilience. However, in some sense he misses a major point that a systems-based approach as provided by Haimes [3,4] is effective for treating complex problems of interacting phenomena more so than treating relationships between elements individually in the context of risk. As such, both researchers provide helpful insights for developing a synthesis framework. Haimes' [3,4] contribution describes how a systems-based approach to vulnerability, risk, and resilience can be effective for characterizing complex (space-time) problems. In terms of the rigor of risk theory, Aven's [34,35] characterization of vulnerability, risk and resilience points out that uncertainty should underlie all three concepts, but for the most part exists within treatments of risk only. However, because vulnerability is considered a part of risk, vulnerability falls under the theoretical frame of risk theories. There have been many lab experiments, field experiments, and field studies about risk-based relations, and their inclusion in risk theory, but few treating complex systems given the complexity of problems [3,4].

In regards to resilience, research has been underway for several decades, with many contributions comparing articulations of resilience across contexts. Within ecological contexts, Holling [36] is often credited with distinguishing ecological risk from engineering risk, characterizing ecosystems as dynamics systems. Adger [37] looks at the difference between the social and ecological contexts, describing similarities, but also differences, particularly in regards to human agents that intentionally direct change as opposed to reactions to change in ecosystems. Manyena [38] and Alexander [39] examine etymologies of resilience and risk in the context of disaster risk reduction, noting that the foundation of resilience comes from the Latin resilio, to 'rebound'. The field of disaster risk reduction has added considerable research about natural hazards to the literature base, particularly in the field of critical and complex systems. Masten [40] examines the foundation of resilience in human systems development from psychological and socio-psychological perspectives using integrated approaches. However, the field of individual human development is not part of the synthesis of resilience treated herein, as it is beyond the scope of this current work focusing on regional community scales. In terms of the rigor of resilience theory, studies of human development provide the largest body of research [40], having been developing over the past 100 years. However, in terms of community/regional resilience which is a rather different scale of treatment of elements, there is very little. The only reference retrieved in the search that has 'resilience theory' in the title (written by Carlson et al. [41] at Argonne National Labs within the context of critical infrastructures), contains 60 instances of the term 'theory'. All but three are part of the title tag line at the top of every report page. One of the other three appears in a phrase 'from theory to practice', and the other two appear in reference citations. A paucity of retrieval results about resilience theory suggests an infancy of development, perhaps due to the complexity of the topic. However, 
conceptual frameworks abound within the literature (as analyzed below), suggesting that conceptual frameworks are the extent of development.

In regards to sustainability as a fourth major concept to emerge among V-R-R-S components in research literature, the term has become very popular principally due to its use by the UN Commission on Environment and Economic Development through publication of Our Common Future [42]. The work of Kates et al. [43] in developing sustainability science was the next major push, of which the US National Academy of Science National Research Council vulnerability analysis framework was part [2]. In terms of the rigor of sustainability theory, Purvis, Yao, and Robinson [44] explore the origins of the three (social, economic and environmental) pillar description of sustainability, commonly represented as a Venn diagram of three overlapping circles. Nowhere did they find a theoretically rigorous description of the framework, suggesting that this absence of rigorous treatment inhibits making the concept operational.

The above findings about emergence of concepts and theoretical rigor in risk only, call into question the relationships between conceptual frameworks and theory. From the perspective of theory-based concepts, V-R-R-S can be said be said to be evaluative conditions in complex decision theory. DeSanctis and Poole's [45] Adaptive Structuration Theory of small-group decision making was developed from concepts and relations that tested for efficacy across a decade of research. Based on that success in decision theory, Nyerges and Jankowski [46] examined fourteen conceptual frameworks, and synthesized from them Enhanced Adaptive Structuration Theory as the start of their effort for another two decades of research into collaborative spatial decision theory $[13,28]$, subsequently ranging from small to very large group-based decision situations, some involving evaluative conditions such as vulnerability, risk and sustainability criteria, with a notable absence of resilience criteria. In separate and complementary research about common pool resource decision making, Poteete, Janssen, and Ostrom [47] describe how the development of theory arises from first articulating conceptual frameworks as an expression of concepts related to other concepts (that make sense to some/many people), from which statements of relationships are articulated to elucidate hypotheses, and then these hypotheses are translated into operational models for testing the hypotheses through a variety of methods to assess the statistical veracity of the statements. Once statements and models demonstrate veracity, then and only then do the statements get elevated to the idea of 'premises' among concepts, and these collections of concepts and premises start to form the basis of theory [45-47]. As such, in decision theory, conceptual frameworks precede formulation of theories. Theories develop in advance of premises, requiring testing of hypotheses and models, and hence rely on articulation of conceptual frameworks to get things started. Given this approach to theory development, this paper suggests that a rigorous VRRSability conceptual framework will spawn rigorous hypotheses, followed by models that can be tested as a move toward VRRSability theory, and welcomes others in that pursuit since it is a rather significant undertaking.

In summary, based on the above overview, we can conclude that vulnerability is generally part of risk, resilience, and sustainability; risk and resilience are conversely related (the flip side of each other), and sustainability would best be understood in the context of monitoring vulnerability, risk and resilience over the long-term. To better articulate the potential for that understanding, below we report on a content analysis that unpacks the individual sub-concepts of the V-R-R-S concepts to gain an appreciation for how the sub-concepts are common among the V-R-R-S concepts as we work toward an operational synthesis.

\subsection{Glossary-Based Analysis of V-R-R-S Definitions for Initiating Conceptual Content Identification}

We use an information gain approach within a list of V-R-R-S sub-concepts to establish a logic for identifying and corroborating sub-concepts. A content analysis used V-RR-S definitions that appear in several credible glossaries published by US Federal and international organizations (Table 1 left-most column). Credibility stems from the use 
of these documents in the practice of the respective organizations, each organization having international stature. At least three references for each concept were used to offer a concept definition, because three definitions from different organizations offer a basis for triangulation among the definitions. As such, a total of eight documents were identified for the content analysis of definitions. The list of definitions and the analysis appears in Appendix A. The information gain approach supports analysis of relationships, i.e., what sub-concepts must initially exist before other sub-concepts can qualify the initial sub-concepts? For example, elements of a system precede relationships between/among elements; thus, the sub-concepts are labeled a to e in order to reflect a "first things first" order of emergence as the basis of information gain.

Table 1. Resulting Analysis of Sub-Concept (phrases expressed as table entry codes a-e ${ }^{1}$ )) and Synthesis into Components.

\begin{tabular}{ccccc}
\hline Definition Source & Vulnerability & Risk & Resilience & Sustainability \\
\hline $\begin{array}{c}\text { US EPA Risk Assessment } \\
\text { Glossary [31,48] }\end{array}$ & ab & abe & & \\
\hline $\begin{array}{c}\text { US FS Risk Terminology Primer } \\
{[32,49]}\end{array}$ & ab & ae & & \\
\hline $\begin{array}{c}\text { United Nations Handbook for } \\
\text { UNISDR Terminology [33,50] }\end{array}$ & abe & abe & abde & abcde \\
\hline $\begin{array}{c}\text { IPCC Managing Risk Report } \\
{[34,51]}\end{array}$ & abe & abcde & abde & abde \\
\hline $\begin{array}{c}\text { Walker and Salt [15] } \\
\begin{array}{c}\text { US EPA Environmental System } \\
\text { Mgt Glossary [35,52] }\end{array}\end{array}$ & & abd & acd \\
\hline $\begin{array}{c}\text { Resilience Alliance Glossary } \\
{[36,53]}\end{array}$ & & abcde & abcde \\
\hline $\begin{array}{c}\text { American Society of Civil } \\
\text { Engineers [37,54] }\end{array}$ & & abce & abde & abcde \\
\hline $\begin{array}{c}\text { Synthesis of Entries for the } \\
\text { Respective Column }\end{array}$ & abe & & & acde \\
\hline
\end{tabular}

${ }_{1}$ Table entry codes: a: system elements (e.g., stressor or receptor), each element characterized in terms of some level of functional performance. b: functional performance exposure relationship between elements. c: doseresponse threshold(s) related to harm or functional performance. $d$ : management action to address functional performance of that relationship. e: functional performance outcome from the relationship.

An enumeration of sub-concepts across all definitions for a VRRS concept was performed with results depicted in Table 1. A majority of entries must include a sub-concept before that sub-concept (a-e) represents a conceptual component (a-e) as indicated within the synthesis summary (last) row of the table. As such, the VRRS concepts appear as labeled components below.

Vulnerability $(\mathrm{a}, \mathrm{b}, \mathrm{e})$ - system elements, functional performance exposure, and performance outcome considering sensitivity of element.

Risk (a,b,c,e)-system elements, functional performance exposure, and probability of performance outcome with damage at a given level.

Resilience ( $a, b, d, e)$-system elements, functional performance process including feedback, management action, functional performance outcome. Emphasizing outcomes over future times.

Sustainability (a,b,c,d,e)—system elements, functional performance process, performance dose response, management action, and functional performance outcome. Emphasizing outcomes over future time.

In the summary list of conceptual components, vulnerability has three components $(a, b, e)$, whereas risk has four $(a, b, c, e)$, Vulnerability treats outcome in terms of sensitivity, 
and risk treats outcome in terms of probability of damage at a given dose threshold. Vulnerability is often seen as a qualitative concept (with the phrase 'at risk' being used in popular communications, such as TV news). Sensitivity to harm of the functional performance of a receptor element is a key issue, but details of exposure to stressors/hazards do not appear as part of vulnerability relationships. The concept of risk commonly adds dose response (c) to the elements, but in this definitional enumeration of risk sub-concepts $(a, b, e)$, the majority of definitions do not include it. Much of the resilience literature includes the concept of (dose-response) threshold, but only two of the definitions highlight thresholds. As such, a threshold does not appear among the components $(a, b, d, e)$. Sustainability definitions contain all of the sub-concepts $(a, b, c, d, e)$. We conclude from this circumstance that sustainability is the broadest of terms. This might explain why vulnerability and risk are easier to implement within ecosystem, social-ecological systems, and/or coupled natural-human systems assessments, whereas resilience and sustainability are not yet commonly operational for those same contexts, because they are more complex. Furthermore, although sustainability is a broad term, it does not include sensitivity, as does vulnerability, or probability as in risk, or dynamics of exposure as in resilience. Consequently, there appears to be a need for a term encompassing all four concepts that is more comprehensive than all four concepts.

\subsection{Literature Analysis-Based Enumeration of VRRS Conceptual Components}

Informed by the conceptual components identified in Table 1, we examined a collection of VRRS publications for additional insight into conceptual components. The literature collection was developed by specifying all combinations of "vulnerability, risk, resilience, and sustainability" as in paired terms, triplet, and quadruplet combinations in Google Scholar searches, principally. The order of appearance of a term mattered within a search text string, i.e., a somewhat different list of books, articles and reports appeared for each combination in a different sequence. The Google Scholar search approach used a snowballassociation search as a supplement such that additional articles broadened the list of publications. No bias toward "geospatial" publications occurred, i.e., all publications with multiple terms helped broaden the publication collection. References were used when two or more concepts in comparison/contrast were treated, i.e., a reference was not used if a concept was used 'only in passing' without more detailed treatment.

The resulting list of publications (books, articles and reports) formed the basis for enumerating conceptual components, providing concurrence of the definition-based conceptual components as well as additional components (Table 2). The left-most column of Table 2 includes components emerging from the definitional sub-concept synthesis together with others deemed potentially relevant to forming a conceptual framework. Entries within the VRRS columns provide a description of the relevance of each component in regards to the respective concept. The right-most column of the table provides an assessment of how each component contributes to a VRRS synthesis. The overall motivation for this kind of table originates with Miller et al. [55] who treated vulnerability and resilience. However, we have greatly expanded the table to treat risk and sustainability as well, and we have expanded the number of components and resynthesized several of the conceptual component entries with an eventual end goal of implementing all conceptual components as software components as part of future research. 
Table 2. Conceptual components and their relevance within a VRRS synthesis.

\begin{tabular}{|c|c|c|c|c|c|}
\hline $\begin{array}{l}\text { Conceptual } \\
\text { Components } \\
\left(\text { Labels }^{1}\right) \text {. }\end{array}$ & Vulnerability & Risk & Resilience & Sustainability & $\begin{array}{l}\text { Contribution to } \\
\text { VRRS Synthesis }^{2}\end{array}$ \\
\hline $\begin{array}{l}\text { Identity of systems } \\
\text { (social-ecological, } \\
\text { coupled human- } \\
\text { environment, } \\
\text { coupled } \\
\text { natural-human) } \\
\text { (abcde) }\end{array}$ & $\begin{array}{l}\text { Social systems to } \\
\text { social-ecological } \\
\text { systems, human- } \\
\text { environment } \\
\text { systems, and } \\
\text { coupled } \\
\text { natural-human } \\
\text { systems. } \\
{[1-4,15,28,55-64]}\end{array}$ & $\begin{array}{c}\text { SES not treated in } \\
\text { any significant } \\
\text { way, but important } \\
\text { for infrastructure } \\
{[2-4,58]}\end{array}$ & $\begin{array}{c}\text { Move from } \\
\text { ecological toward } \\
\text { social dimensions } \\
\text { within coupled } \\
\text { social-ecological } \\
\text { system } \\
{[1,3,4,55,59,60,62} \\
64-66]\end{array}$ & $\begin{array}{c}\text { Social, economic, } \\
\text { and ecological } \\
\text { dimensions treated } \\
{[1,60,64]}\end{array}$ & $\begin{array}{l}\text { Complementarity } \\
\text { among Vul, Res, } \\
\text { and Sus with } \\
\text { contribution to Ris }\end{array}$ \\
\hline $\begin{array}{l}\text { Stressors/hazards/ } \\
\text { disturbances as } \\
\text { controlling } \\
\text { variables (a1) }\end{array}$ & $\begin{array}{c}\text { Stressor element(s) } \\
{[2,67]}\end{array}$ & $\begin{array}{c}\text { Stressor element(s) } \\
{[10,34,35,67]}\end{array}$ & $\begin{array}{c}\text { Stressor element(s) } \\
\text { and sub-systems } \\
{[10,15]}\end{array}$ & $\begin{array}{c}\text { Stressor element(s) } \\
\text { and sub-systems } \\
{[2,13,67]}\end{array}$ & $\begin{array}{l}\text { Complementarity } \\
\text { between Vul and } \\
\text { Ris with } \\
\text { contribution to Res } \\
\text { and Sus }\end{array}$ \\
\hline $\begin{array}{l}\text { Fast versus slow } \\
\text { change variables } \\
\text { regarding receptor } \\
\text { functional } \\
\text { performance (a2) }\end{array}$ & $\begin{array}{c}\text { Sensitivity of } \\
\text { receptor element(s) } \\
\text { to potential harm } \\
{[2,56,68]}\end{array}$ & $\begin{array}{c}\text { Sensitivity of } \\
\text { receptor element(s) } \\
\text { to probable harm } \\
{[11,34,35]}\end{array}$ & $\begin{array}{c}\text { Sensitivity of } \\
\text { receptor element(s) } \\
\text { or sub-system(s) to } \\
\text { harm or benefit } \\
{[12,15,36,68-70]}\end{array}$ & $\begin{array}{c}\text { Sensitivity of } \\
\text { receptor element(s) } \\
\text { or sub-system(s) to } \\
\text { harm or benefit } \\
\text { [12] }\end{array}$ & $\begin{array}{l}\text { Complementarity } \\
\text { among all, but } \\
\text { each contributes a } \\
\text { different aspect of } \\
\text { change }\end{array}$ \\
\hline $\begin{array}{l}\text { Exposure } \\
\text { relationship(s) (b1) } \\
\text { between elements }\end{array}$ & $\begin{array}{l}\text { Space-time } \\
\text { collocation } \\
{[2,55,67,71]}\end{array}$ & $\begin{array}{l}\text { Space-time } \\
\text { pathway } \\
{[67,68,71-73]}\end{array}$ & $\begin{array}{c}\text { Sub-system to } \\
\text { whole system } \\
{[74]}\end{array}$ & $\begin{array}{c}\text { Sub-system to } \\
\text { whole system } \\
{[75,76]}\end{array}$ & $\begin{array}{l}\text { Ris with } \\
\text { contribution to Vul, } \\
\text { Res, and Sus }\end{array}$ \\
\hline $\begin{array}{c}\text { Event } \\
\text { occurrence(s) (b2) }\end{array}$ & $\begin{array}{c}\text { Commonly single } \\
\text { event } \\
{[75]}\end{array}$ & $\begin{array}{c}\text { Commonly single } \\
\text { event } \\
{[34,35]}\end{array}$ & $\begin{array}{c}\text { Commonly } \\
\text { multiple events } \\
\text { over medium time } \\
\text { frame } \\
{[15,55]}\end{array}$ & $\begin{array}{c}\text { Commonly } \\
\text { multiple events } \\
\text { over an extended } \\
\text { time frame } \\
{[1,2,62]}\end{array}$ & $\begin{array}{l}\text { Complementarity } \\
\text { among Vul, Ris, } \\
\text { Res, and Sus }\end{array}$ \\
\hline $\begin{array}{l}\text { Dose-response } \\
\text { threshold (c) }\end{array}$ & $\begin{array}{c}\text { Potential ordinal } \\
\text { level of sensitivity } \\
\text { to harm } \\
{[2,67]}\end{array}$ & $\begin{array}{c}\text { Probability of } \\
\text { damage outcome } \\
{[34,35]}\end{array}$ & $\begin{array}{l}\text { Tipping point } \\
\text { ranges for unstable } \\
\text { equilibrium } \\
{[15,55,60,70,77,78]}\end{array}$ & $\begin{array}{c}\text { Range of } \\
\text { magnitudes for } \\
\text { satisfactory } \\
\text { performance } \\
{[12,13]}\end{array}$ & $\begin{array}{c}\text { Contribution of Ris } \\
\text { and Res to Vul and } \\
\text { Sus }\end{array}$ \\
\hline $\begin{array}{c}\text { Management } \\
\text { action and capacity } \\
\text { to act (d1) }\end{array}$ & $\begin{array}{c}\text { Plan, adapt, resist } \\
{[2,79,80]}\end{array}$ & $\begin{array}{c}\text { Plan, adapt, resist } \\
\text { [81] }\end{array}$ & $\begin{array}{l}\text { Plan, adapt, resist, } \\
\text { recover } \\
{[22,62,82-87]}\end{array}$ & $\begin{array}{c}\text { Plan, maintain } \\
{[22,60,79,84]}\end{array}$ & $\begin{array}{l}\text { Complementarity } \\
\text { of Ris and Res with } \\
\text { contribution to Vul } \\
\text { and Sus }\end{array}$ \\
\hline $\begin{array}{l}\text { Agency for taking } \\
\text { action }(\mathrm{d} 2)\end{array}$ & $\begin{array}{l}\text { Medium } \\
{[2,56,68]}\end{array}$ & $\begin{array}{c}\text { Strong } \\
{[3,4,34,35]}\end{array}$ & $\begin{array}{l}\text { Strong } \\
{[21,62,63]}\end{array}$ & $\begin{array}{l}\text { Medium } \\
\text { [87] }\end{array}$ & $\begin{array}{l}\text { Complementarity } \\
\text { of Ris and Res with } \\
\text { contribution to Vul } \\
\text { to Sus }\end{array}$ \\
\hline $\begin{array}{l}\text { Empowerment of } \\
\text { social group(s) to } \\
\text { address conditions } \\
\text { (d3) }\end{array}$ & $\begin{array}{l}\text { Strong } \\
{[88,89]}\end{array}$ & $\begin{array}{l}\text { Strong } \\
\text { [88] }\end{array}$ & $\begin{array}{l}\text { Strong } \\
{[15,55,90]}\end{array}$ & $\begin{array}{l}\text { Strong } \\
{[2,28,87]}\end{array}$ & $\begin{array}{l}\text { Complementarity } \\
\text { among Vul, Ris, } \\
\text { Res, and Sus }\end{array}$ \\
\hline $\begin{array}{l}\text { Impact/influence } \\
\text { reduc- } \\
\text { tion/improvement } \\
(\mathrm{e} 1)\end{array}$ & $\begin{array}{c}\text { Strong } \\
{[2,28,67,91]}\end{array}$ & $\begin{array}{c}\text { Strong } \\
{[34,35,67,68]}\end{array}$ & $\begin{array}{c}\text { Strong } \\
{[15,22,63,86]}\end{array}$ & $\begin{array}{l}\text { Strong } \\
{[22,64,91]}\end{array}$ & $\begin{array}{l}\text { Complementarity } \\
\text { among Vul, Ris, } \\
\text { Res and Sus }\end{array}$ \\
\hline $\begin{array}{l}\text { Decision trade-offs } \\
\text { and priorities }(\mathrm{e} 2)\end{array}$ & $\begin{array}{c}\text { Weak treatment } \\
{[5,67]}\end{array}$ & $\begin{array}{c}\text { Strong treatment } \\
{[11,67]}\end{array}$ & $\begin{array}{c}\text { Medium treatment } \\
{[55,63]}\end{array}$ & $\begin{array}{c}\text { Medium treatment } \\
{[13,92]}\end{array}$ & $\begin{array}{l}\text { Complementarity } \\
\text { among Vul, Ris, } \\
\text { Res and Sus }\end{array}$ \\
\hline
\end{tabular}


Table 2. Cont.

\begin{tabular}{|c|c|c|c|c|c|}
\hline $\begin{array}{l}\text { Conceptual } \\
\text { Components } \\
\left(\text { Labels }^{1}\right) .\end{array}$ & Vulnerability & Risk & Resilience & Sustainability & $\begin{array}{l}\text { Contribution to } \\
\text { VRRS Synthesis }\end{array}$ \\
\hline $\begin{array}{l}\text { Transformation as } \\
\text { long-term } \\
\text { structural change } \\
\text { (e3) }\end{array}$ & $\begin{array}{c}\text { Avoid exposure } \\
\text { over long-term } \\
{[55]}\end{array}$ & $\begin{array}{l}\text { Avoid harm over } \\
\text { long-term }\end{array}$ & $\begin{array}{c}\text { Resourcefulness } \\
\text { over long-term } \\
{[81,93]}\end{array}$ & $\begin{array}{c}\text { Maintain over } \\
\text { long-term } \\
{[13,61]}\end{array}$ & $\begin{array}{l}\text { Complementarity } \\
\text { of Res and Sus } \\
\text { with contribution } \\
\text { to Vul and Ris }\end{array}$ \\
\hline Scenarios (f) & $\begin{array}{c}\text { Normal, chronic, } \\
\text { severe, } \\
\text { catastrophic } \\
{[94,95]}\end{array}$ & $\begin{array}{c}\text { Normal, chronic, } \\
\text { severe, } \\
\text { catastrophic } \\
\text { [73] }\end{array}$ & $\begin{array}{c}\text { Severe, } \\
\text { catastrophic } \\
{[73,95]}\end{array}$ & $\begin{array}{c}\text { Normal, chronic } \\
{[14]}\end{array}$ & $\begin{array}{c}\text { Complementarity } \\
\text { between Vul, Ris, } \\
\text { Res, and Sus }\end{array}$ \\
\hline $\begin{array}{l}\text { Spatial, temporal, } \\
\text { attribute Scale }(\mathrm{g})\end{array}$ & $\begin{array}{c}\text { Macro, meso, } \\
\text { micro } \\
{[2,55,67,84,96]}\end{array}$ & $\begin{array}{c}\text { Micro or meso } \\
\text { [67] }\end{array}$ & $\begin{array}{c}\text { Macro, meso, } \\
\text { micro } \\
{[55,66,82,84,96,97]}\end{array}$ & $\begin{array}{c}\text { Macro, meso, } \\
\text { micro } \\
{[6,13,93,98,99]}\end{array}$ & $\begin{array}{l}\text { Complementarity } \\
\text { among Vul, Res, } \\
\text { and Sus with } \\
\text { contribution to Ris }\end{array}$ \\
\hline $\begin{array}{l}\text { Levels of } \\
\text { resolution for units } \\
\text { of analysis (h) }\end{array}$ & $\begin{array}{c}\text { Element(s) } \\
{[34,35,55,100]}\end{array}$ & $\begin{array}{c}\text { Element(s) } \\
{[3,4,34,35,100,101]}\end{array}$ & $\begin{array}{c}\text { Sub-system(s) } \\
{[55,100]}\end{array}$ & $\begin{array}{c}\text { Element(s), } \\
\text { sub-system(s), } \\
\text { system(s) } \\
{[1,59,101,102]}\end{array}$ & $\begin{array}{l}\text { Complementarity } \\
\text { among Vul, Ris, } \\
\text { Res and Sus }\end{array}$ \\
\hline Feedback (i) & $\begin{array}{l}\text { Weak, not } \\
\text { identified } \\
\text { explicitly }\end{array}$ & $\begin{array}{l}\text { Weak, not } \\
\text { identified } \\
\text { explicitly }\end{array}$ & $\begin{array}{c}\text { Strong, explicitly } \\
\text { identified } \\
{[6,15,103,104]}\end{array}$ & $\begin{array}{c}\text { Medium, generally } \\
\text { identified } \\
{[6]}\end{array}$ & $\begin{array}{c}\text { Contribution of } \\
\text { Res to Vul, Ris and } \\
\text { Sus }\end{array}$ \\
\hline $\begin{array}{c}\text { Alternate stable } \\
\text { states }(\mathrm{j})\end{array}$ & $\begin{array}{l}\text { Weak, except for } \\
\text { livelihood or } \\
\text { governance } \\
\text { strategies }\end{array}$ & $\begin{array}{l}\text { Weak, different } \\
\text { conditions of } \\
\text { stability }\end{array}$ & $\begin{array}{c}\text { Strong, diverse } \\
\text { conditions of } \\
\text { stability } \\
{[15,81,82]}\end{array}$ & $\begin{array}{l}\text { Medium, similar } \\
\text { conditions of } \\
\text { stability } \\
{[60]}\end{array}$ & $\begin{array}{l}\text { Res contribution to } \\
\text { Vul, Ris and Sus }\end{array}$ \\
\hline $\begin{array}{l}\text { Social learning } \\
\text { about VRRS } \\
\text { conditions }(\mathrm{k})\end{array}$ & $\begin{array}{c}\text { Individual, small- } \\
\text { and medium-size } \\
\text { groups } \\
{[56,105]}\end{array}$ & $\begin{array}{c}\text { Individual, small, } \\
\text { and medium-size } \\
\text { groups } \\
{[31,67]}\end{array}$ & $\begin{array}{c}\text { Participatory } \\
\text { large-size groups, } \\
\text { community } \\
{[55,90,106]}\end{array}$ & $\begin{array}{c}\text { Participatory } \\
\text { large-size groups, } \\
\text { community } \\
{[6,31,61,87,107,} \\
108]\end{array}$ & $\begin{array}{l}\text { Complementarity } \\
\text { of Res and Sus } \\
\text { with contribution } \\
\text { to Vul and Ris }\end{array}$ \\
\hline $\begin{array}{c}\text { Knowledge } \\
\text { systems about } \\
\text { VRRS conditions } \\
\text { (l) }\end{array}$ & $\begin{array}{l}\text { Strong } \\
{[3,4,67]}\end{array}$ & $\begin{array}{l}\text { Strong } \\
{[3,4,67]}\end{array}$ & $\begin{array}{c}\text { Strong } \\
{[10,63,86]}\end{array}$ & $\begin{array}{c}\text { Strong } \\
{[13,100,105,109]}\end{array}$ & $\begin{array}{l}\text { Complementarity } \\
\text { among Vul, Ris, } \\
\text { Res and Sus }\end{array}$ \\
\hline $\begin{array}{c}\text { Operational } \\
\text { implementation } \\
(\mathrm{m})\end{array}$ & $\begin{array}{l}\text { Advanced } \\
{[3,4,11,67]}\end{array}$ & $\begin{array}{l}\text { Advanced } \\
{[3,4,11,67]}\end{array}$ & $\begin{array}{c}\text { Emerging } \\
{[10,55,63,70,86]}\end{array}$ & $\begin{array}{c}\text { Emerging } \\
{[5,6,22]}\end{array}$ & $\begin{array}{c}\text { Complementarity } \\
\text { among Vul, Ris, } \\
\text { Res, and Sus }\end{array}$ \\
\hline $\begin{array}{c}\text { Summary list of } \\
\text { V-R-R-S } \\
\text { components }\end{array}$ & $\begin{array}{c}a, b, e, \\
f, g, h, k, l, m\end{array}$ & $\begin{array}{c}a, b, c, e \\
f, g, h, k, l, m\end{array}$ & $\begin{array}{c}\mathrm{a}, \mathrm{b}, \mathrm{d}, \mathrm{e}, \\
\mathrm{f}, \mathrm{g}, \mathrm{h}, \mathrm{i}, \mathrm{j}, \mathrm{k}, \mathrm{l}, \mathrm{m}\end{array}$ & $\begin{array}{c}a, b, c, d, e \\
f, g, h, k, l, m\end{array}$ & $\begin{array}{c}\mathrm{a}, \mathrm{b}, \mathrm{c}, \mathrm{d}, \mathrm{e}, \\
\mathrm{f}, \mathrm{g}, \mathrm{h}, \mathrm{i}, \mathrm{j}, \mathrm{k}, \mathrm{l}, \mathrm{m}\end{array}$ \\
\hline
\end{tabular}

\footnotetext{
${ }^{1}$ Conceptual component labels $(\mathrm{a}-\mathrm{m})$ uniquely identify each component for each set of the references. ${ }^{2}$ Vul: vulnerability; Ris: risk; Res:
} resilience; Sus: sustainability.

The order of the conceptual components within Table 2 uses an approximation of information gain, i.e., a first-things-first approach, which is the same as the ontological content, structure, process, and context strategy of the overall MOESIR framework [1]. The earlier a row appears in Table 2, the more fundamental a component. Twenty components emerged from the respective literature, originally. By comparing, contrasting, and integrating concepts, thirteen components emerge as a synthesis (labels a-m designated in the left-most column of Table 2). Components labeled a to e are the same as in Table 1. The literature was helpful for identifying significant refinements/nuances for components a to e; designated by integer numbers following a component label a to e (e.g., a\#, b\#, etc.) to detail and refine the respective components. Detail refinements emerged through a 
process of multiple-pass iteration. Below we highlight important aspects of the thirteen components $(\mathrm{a}-\mathrm{m})$ and their associated sub-component details using information gain, aligning Tier 1 elements and relationships to Tier 2 components and sub-components, to characterize systems content (a), structure (b), process dynamics (c,d,e), and context (f-m) of a decision problem.

\subsubsection{Identity of and within Integrated Systems (a to e)}

A considerable body of systems-oriented research examines VRRS conditions. Tompkins and Adger [56] explore social vulnerability within social-ecological systems using a qualitative approach, whereas Luers [57] explores vulnerability of agriculture for a humanenvironment system using a quantitative approach. Haimes [58] sees vulnerability as part of risk, wherein states of conditions express system; a state characterizes a collection of system conditions. Walker and Salt [15] outlined 'resilience thinking' as one of the better elucidations of a social-ecological systems perspective. Sahely and Kennedy [59] use a system approach to model the urban water cycle using flows of water, energy, and chemicals and associated greenhouse gas emissions moving through the urban water infrastructure system. MOESIR Tier 1 characterizes complex systems [1], emphasizing relationships for scaffolding information from Tier 1 systems to Tier 2 VRRS concepts. A robust systems characterization makes use of methods from ecological topology involving both discrete connected objects and continuous fields [60], particularly for characterizing complex socialecological systems. These are two perspectives for characterizing systems, each associated with particular representations of relationships that would offer different advantages. $\mathrm{Ny}-$ erges et al. [28] investigated the interaction among ten sub-systems (five vulnerable and five developable) using a geodesign workflow to examine urban sustainable watershed development, but treating vulnerability by itself was concluded to be somewhat limited for systems evaluation.

Synthesizing across concepts, Folke et al. [61] were among the first to recognize the importance of linkages among vulnerability, resilience, and sustainability with regard to social-ecological systems. Bruneau et al. [62] explored interconnections among infrastructure systems as "lifelines" using vulnerability, risk and resilience perspectives. From a comprehensive VRRS perspective, Turner et al. [2] and Turner [5] speak to the importance of coupled human-environment systems, highlighting more than a dozen sub-concepts as part of VRRS. Miller et al. [55] remark that vulnerability and resilience research, with risk and sustainability perspectives, should focus on linking perspectives on social-ecological systems, and draw upon the strengths of systems thinking in understanding dynamic social-ecological relations, and actor-oriented approaches in understanding matters of social differentiation, equity, and power. Schultz and Smith [63] examine resilience of infrastructure as a human-environment system using a Bayesian approach, and recognize the complementarity to risk assessment. Lounis and McAllister [64] focus on the development of infrastructure systems that are to be sustainable and resilient.

Recognizing the diversity of those views about VRRS of complex systems, where does one start with an ontological elucidation of components? Identity is thought to be a first step for characterizing (what, how, when, and how much) relationships within integrated social-ecological systems, coupled human-environment systems, and coupled natural-human systems, as a basis of problem definition $[48,49]$. A clear system identity (elements and relationships) provides a baseline interpretation for VRRS to articulate criteria (e.g., performance sensitivity for vulnerability) and measure change (impact level on performance in risk) to address functional performance of a system [4]. Haimes [3] and Cumming [66] suggest that a complex systems specification is necessary when modelling functional performance, the former for risk to infrastructure systems and the latter for resilience of ecosystems.

The following observations summarize a system identity perspective for VRRS conditions. Identity for system vulnerability focuses on sensitivity of functional performance, given many diverse disturbance conditions. Identity for system risk focuses on the probability of 
damage to functional performance, given specific disturbance conditions. Identity for system resilience focuses on improvements to functional performance, given diverse disturbance conditions. Identity for system sustainability focuses on maintaining long-term levels of functional performance, given many diverse disturbance conditions. As such, identity takes on four different, but complementary thrusts, reinforcing motivation for this effort. Overall, the complementarity that exists among vulnerability, resilience and sustainability can contribute to improving an understanding of risk conditions associated with system identity. Furthermore, although identity is an important initial step, further understanding about identity of system elements and relationships emerges from details of the components a to e as described below.

- Stressors, hazards, disturbances, and controlling variables influence functional performance (a1)

Hazards and stressors are synonyms within the vulnerability and risk literature ( $\mathrm{Ny}-$ erges, Robkin and Moore 1997) [67]. The vulnerability-sustainability literature considers both natural and human-made hazards as important generators of socially or physically vulnerable circumstances, but sensitivity to diverse disturbances is a key issue [2]. The disaster risk literature recognizes diverse hazards at a community scale that can influence receptors in various ways [10]. Hazards as stressors are key to understanding the probability and magnitude of risk consequences [34,35]; various granularities being considered. In the social-ecological literature about resilience, disturbances and controlling variables are synonyms [15]. The sustainability literature treats a wide array of stressors, hazards, and disturbances [13]. In summary, stressors (and its synonyms) exist for all VRRS conditions, but the specific and diverse character of those stressors will have varying influences on functional performance or other variables. The complementarity that exists between vulnerability and risk, can contribute to a better understanding of stressor conditions for resilience and sustainability.

- Fast versus slow change variables regarding receptor functional performance (a2)

Turner et al. [2] and Tompkins and Adger [56] see receptor vulnerability as having a sensitivity component; different receptors are more sensitive to certain social-economicecological-physical conditions than are other receptors. Adger [68] treats vulnerability, risk, and adaptive capacity (an aspect of resilience) while generalizing metrics for vulnerability that incorporate receptor change sensitivity within social and physical domains. Aven $[34,35]$ suggests that risk includes uncertainty of probability to qualify our understanding of damage to receptors; as uncertainty is significant for risk-based decision making [11]. Holling [36] differentiated engineering resilience and ecological resilience by noting that an engineering perspective focuses on change recovery characterized as static equilibrium for physical receptors using a narrow range of functional performance; whereas an ecological perspective focuses on change recovery characterized as dynamic equilibrium using a broad range of receptor (species) functional performance. McLellan et al. [69] describe how the tsunami disaster in Japan in 2011 brought into focus the importance of resilience and risk mitigation of energy infrastructure performance. Walker and Salt [15] focus on controlling variables that influence variables of concern, e.g., as receptor functional performance. Mumby et al. [70] examine the spatial distribution of resilience on coral reefs as receptors impacted by varying conditions, some physical, while others are biological. Minsker et al. [12] examine the potential for synthesizing perspectives about resilience and sustainability of performance-based metrics for characterizing infrastructures as receptors, as it is timely and important to recognize resilience and sustainability complementarity. In summary, receptor functional performance can behave in either fast or slow ways depending on the nature of the influence from stressors as a basis for humanenvironment and social-ecological interactions in terms of fast versus slow changes. The complementarity among all VRRS concepts, each different but related, should improve understanding of change.

- Exposure pathway relationship(s) between elements—stressors and receptors (b1) 
Nyerges, Robkin, and Moore [67] examine the difference between vulnerability and risk, recognizing that exposure pathway and dose response were among the main differences. Collocation of exposure with no or little information about stressor dose is at the core of vulnerability [2], whereas exposure pathway with measured dose-response is at the core of risk [34]. Using different perspectives, some researchers view vulnerability and risk as conceptually distinct [71]. Wisner et al. [72] and Leh, Bajwa and Chaubey [73] review urban land impacts related to erosion risk, recognizing that increases in land use and land cover cause negative effects on stream water quality and quantity plus stream ecosystem health over time. Rodriguez-Nikl et al. [74] report on a synthesis linking conceptual perspectives about short-term aspects of disaster resilience and long-term aspects of sustainability for system infrastructures in the context of natural disaster events, wherein exposure pathway plays a significant role in information discovery over time. Birkmann $[75,76]$ addresses sustainability from a long-term perspective. In summary, collocated exposure of stressor to receptor is required for establishing VRRS relationships, but exploration of such relationships depends on the measurement specificity of exposure over time. Since exposure pathway is well known in the risk literature, this concept adds more insight to VRRSability than do vulnerability, resilience and sustainability. Probabilistic exposure pathways offer very useful insight for understanding processes and outcomes when examining VRRSability.

- Event occurrence(s)—combining stressor and receptor at some magnitude (b2)

Events occur under various conditions. Some researchers describe an onset of a hazard as an event within a vulnerability context [75], whereas other researchers describe exposure collocation of stressor and receptor as an event within a risk context [34,35]. Miller et al. [55] describe events within vulnerability and resilience contexts as collocations of stressorreceptors during slow and rapid changes. Walker and Salt [15] recognize the interaction of controlling variables and variables of concern as event states across time. Frequent events across an extended timeframe compose chronic conditions from a sustainable development perspective, while some events could be catastrophic in magnitude and thus connect with a resilience perspective $[1,2,62]$. In summary, stressor events and stress-receptor events are two types of events, but the latter is required to address VRRS of receptor functional performance over time. All four concepts offer contributions to overall VRRSability.

- Dose-response threshold (c)

A principal difference between vulnerability and risk deals with measurement of dose-response; wherein we measure dose on an ordinal scale for vulnerability and on an interval scale for risk [67]. Turner et al. [2] see receptors having certain sensitivities to hazards in vulnerability, wherein sensitive receptors are easily impacted and less sensitive receptors are less easily impacted. In relation to risk, dose-response is an inherent part of computing probabilities [34]. In relation to resilience, thresholds act as boundaries between system (stability) states. Crossing a threshold involves a change in the character and extent of feedback associated with a variable of concern such as water quality. Identifying thresholds is not only a question of science, but also involves a value judgment, e.g., climate change influences on ecosystems [55] and agriculture [77]. As an organizing perspective for thresholds, catastrophe theory addresses abrupt changes in state aligned with slow moving parameter changes that result in fast variable outcomes [60]. Horan et al. [78] develop scenario analyses for exploring thresholds within coupled human-environment systems. Walker and Salt [15] present four profiles (curves) for conceptually representing different relationships between a controlling variable and a variable of concern, each considered a scenario that incorporates threshold conditions. Mumby et al. [70] empirically demonstrate a threshold change using a graph that portrays the relationships suggested by Walker and Salt [15]. Considering a range of magnitudes will help identify satisfactory levels of performance for sustainability management $[12,13]$. In summary, dose-response thresholds are key to understanding interaction dynamics between stressor influences on receptor functional performance within condition states over time. Thus, significant contributions 
from the vulnerability and risk literature offer more significant contributions to resilience and sustainability insights, which in turn offer insight when examining VRRSability.

- Management action and capacity to act (d1)

Considerable literature treats management actions associated with VRRS conditions, since examining VRRS conditions influences management conditions. Turner et al. [2], Brooks [79], and Smith and Wandel [80] recognize the importance of vulnerability management. $\mathrm{Ng}$ and Loosemore [81] discuss risks facing large infrastructure projects and distributing these risks among private and public financial organizations that fund such projects as private-public partner management action. Early resilience literature distinguished actions based on infrastructure systems versus ecosystems. Bruneau et al. [62] describe four resilience properties—robustness, redundancy, resourcefulness, and rapidityof infrastructure systems influenced by seismic hazards, with each associated with a form of management action addressing functional performance. Robustness addresses sensitivity. Redundancy addresses multiple and similar options. Resourcefulness addresses new and different options. Rapidity addresses the timeframe for recovery. From an ecosystem perspective, Walker et al. [82] describe four characteristics-latitude, resistance, precariousness, and panarchy-of resilience. A management action can move functional performance away from or closer to the current state of system thresholds by altering latitude. An action can make a threshold more difficult or easier to reach by altering resistance. An action could move the current state of system performance away from or closer to the threshold by altering precariousness. Finally, an action can foster cross-scale interactions to avoid or generate loss of resilience at the largest and most socially catastrophic scales by altering panarchy, which is a three-tier-micro, meso, and macro-spatial-temporal scaling of how transition occurs within ecosystems [83]. As such, characterizing systems process temporality in terms of phases can lead to significant insight for management action.

Toward more synthesis across VRRS conditions, Brooks [79] treats vulnerability, risk, and adaptation, treating 'adaptation' from a perspective on 'what to do' as a management action. Smit and Wandel [66] recognize that adaptation, adaptive capacity, vulnerability, resilience, exposure, and sensitivity as related to management action. Romero-Lankao and Dodman [84] perform an analytical review of the interactions between urbanization and global environmental change in which they see the opportunity of turning hazards causing human pressures on the environment into sources of opportunities and innovations, which offer insights about management actions important for building more resilient and sustainable cities. Bocchini et al. [22] make a distinction between a coping response and an adaptation response based on temporal scale; coping generally describes a short-term response, whereas adaptation generally describes a longer-term response. Ganin et al. [85] describe before, during and after stages of an event in relation to resilience, each type associated with (or requiring) a management action. A before action involves planning and mitigation. A during action involves coping and absorbing. An after action involves recovery. Lam et al. [86] examine the relationship between vulnerability and adaptation to hurricanes along the US Gulf Coast over several decades to gain understanding about how counties (as communities) have responded to hurricanes. They use social-economic characteristics of communities to estimate the management action occurring for each county. Schultz and Smith [63] report on the types of management actions that could protect communities and help them recover once there is an understanding of the potential change that can occur with infrastructures on Long Island, New York. In regards to sustainability, Brooks [79], Romero-Lanko and Dodman [84], Bocchini et al. [22], and Prager and Reiners [60] consider various aspects of action as part of sustainability management. In summary, evaluation of spatial-temporal-functional conditions associated with system service performance leads to informing needs for different types and granularities of management actions for influencing those conditions, and thus service enhancement over space and time. Characterizing temporality of system processes in terms of phases from the risk and resilience literature can lead to significant insight for management action involving vulnerability and sustainability, and consequently VRRSability. 
- $\quad$ Agency to take action (d2)

Turner et al. [2], Tompkins and Adger [56], and Adger [68] describe the importance of organizational agency in the context of vulnerability. Haimes [3,4] and Aven [34,35] briefly describe the significance of agency action in risk management. Bruneau et al. [45] focus on social units (organizations and communities) as agents to address resilience actions. Some researchers describe how resilience action can be part of risk management actions, providing insight from complementary perspectives [21,63]. Individual, group, and community organizations demonstrate agency for taking action to improve well-being in vulnerability, resilience and sustainability contexts [56,68]. Ostrom [87] reports on stakeholders taking action to address their concerns about sustaining resources, despite government organization actions that often move in contrasting directions. In summary, agency to take action can stem from public, private, not-for-profit, and/or community sectors, wherein broadly motivated agency is more forceful than narrowly motivated agency. The complementarity of risk and resilience offer a contribution to vulnerability and sustainability; thus, agency is of considerable importance when addressing VRRSability actions.

- Empowerment of a social group to address conditions (d3)

Kasperson et al. [88] address social amplification of risk, wherein different social groups view hazards differently; some groups command greater resources and thus are more empowered than others to address impacts. Baker [89] reports on how the term disaster is socially constructed and that vulnerability is a dynamic process that depends on a host of contextual factors, so part of this social construction difference is due to the difference in empowerment. Miller et al. [55] recommend methodological improvements in terms of hybrid and pluralistic approaches that elicit input from stakeholders affected by disasters and stresses, because those most affected are rarely, and only to a limited extent, part of studies. Walker and Salt [15] concur that resilience assessment should include stakeholder empowerment. Goldstein [90] describes how collaborative resilience offers stakeholder groups ways to participate in collaborative decision processes, with the understanding that stakeholders should be part of decision processes that affect them. Turner et al. [2] were among the early researchers to connect empowerment in vulnerability and sustainability. Ostrom [87] reports findings that some government policies accelerate resource destruction, whereas some resource users have invested their time and energy to achieve sustainability. Some of that difference is due to certain groups having intimate knowledge of resource behavior, which is a difference in social empowerment. That difference suggests how stakeholder communities often have as good insight as government regulators, if not better insight, and understanding about how to maintain sustainability in resource-oriented social-ecological systems. Geodesign workshops about sustainable watershed development always should include a stakeholder empowerment component [28]. In summary, a complementarity emerges among all four V-R-R-S concepts; and as such, empowerment of stakeholder/social groups will likely broaden and deepen perspectives when considering VRRSability conditions.

- Impact or Influence Reduction (e1)

Most V-R-R-S literature recognizes the importance of performance impacts, because performance impacts as outcomes from influences are relevant to stakeholders concerns about V-R-R-S conditions. The condition of impacts is different for each. Vulnerability is a matter of potential (ordinal-measured) impacts $[2,28,67,91]$. Risk is a matter of actual (interval-measured) impact, including the probability impact magnitude $[34,35,67,68]$. Resilience includes a perspective on disturbance, plus potential response, which could result in impact as a long-term influence on sustainable performance [15]. Both resilience and sustainability focus on level of functional performance as an impact [22,63,86]. Bocchini et al. [22] describe how resilience focuses on low probability of occurrence and high consequence impacts, whereas sustainability focuses on high probability of occurrence and low consequence impacts, distributed over the entire life cycle of infrastructure. Although that perspective appears to simplify making a distinction between resilience and sustainability, 
it masks a nuance that resilience is more about process, while sustainability is more about outcomes [91]. Lounis and McAllister [64] focus on the development of infrastructure systems that are to be sustainable and resilient, suggesting that resilient processes lead to sustainable impacts, which aligns with Redman's [91] processes versus outcomes distinction. In summary, the complementarity among all four concepts suggests that impact(s) on functional performance is perhaps the most fundamental issue when treating VRRSability evaluation of systems; it aligns with a receptor's most salient variable(s) of concern about conditions of outcomes.

- Decision trade-offs and priorities (e2)

Nyerges, Robkin, and Moore [67] describe how risk evaluation within risk assessment incorporates vulnerability assessment; both involve criteria and option trade-offs within multi-criteria decision making. Turner [5] describes how decision trade-off is a pivot point for linking resilience and sustainability perspectives. Barker and Haimes [11] examine trade-offs in risk decision making. Miller et al. [55] recommended assessment frameworks be developed for decision-making methods that can connect vulnerability, risk, resilience, and sustainability. Schultz and Smith [63] use a Bayesian approach for exploring resilience of decision trade-offs for critical infrastructure along Long Island, New York. Nyerges and Jankowski [13] present methods and techniques for implementing decision tradeoffs for participatory sustainability management. Aguirre and Nyerges [92] examine agent-based models that implement scenario-based decision trade-offs for sustainability management. In summary, trade-offs commonly form the core of decision techniques, particularly when values emerge from diverse stakeholder perspectives that encourage different priority setting of impacts. However, the complementarity among the four concepts within the context of decision trade-offs must be further unpacked; that is, we need to better understand what and how conditions are being traded-off to offer necessary and sufficient insights using VRRSability.

- Transformation as long-term structural change (e3)

Miller et al. [55] describe how transformation and adaptation should draw from the vulnerability community in the subjective domain of values, power, and social differentiation. However, at the same time, addressing the environmental consequences of different recovery and adaptation options remains a challenge within studies of vulnerability. Walker et al. [81] explore the resilience, adaptability, and transformability of the capacity to create a fundamentally new system when ecological, economic, or social (including political) conditions make the existing system untenable. Olsson, Galaz, and Boonstra [93] examine how resilience thinking, focused on social-ecological systems, contributes to studies about sustainability transformations. They suggest focusing on innovation and socialecological-technological systems interactions, patterns of transformation, and agency and transformation. Sustainability involves long-term transformations supported through governance change across generations [13,61]. In summary, transformation is among the least understood V-R-R-S components to attract attention, perhaps because transformation relies on so many of the other components that influence long-term structural change. Noticeably, no research has treated transformation explicitly in terms of risk, although we can expect stressor impacts to cause transformations. Concept complementarities suggest that the concepts of resilience and sustainability should be adding transformational insights to the concepts of vulnerability and risk when considering VRRSability.

\subsubsection{Scenarios $(\mathrm{f})$}

Any articulation of a system necessarily includes assumptions about conditions, which we call a scenario. Swart, Raskin, and Robinson [94] suggest that one way to identify system functional performance and the threshold(s) associated with them would be to address them within the context of scenarios. Kjeldsen and Rosbjerg [95] review estimators of reliability, resilience, and vulnerability (R-R-V) and examine which combination of these would be the most appropriate for use in connection with a multi-objective risk assessment 
of a water resources system that forms a sustainability scenario as the product of R-R-V. Leh, Bajwa, Chaubey [73] construct land use scenarios to perform geospatial analyses for exploring risk of erosion processes in watersheds. Linkov et al. [17] array conditions about events to form normal, chronic, acute (severe), and catastrophic scenarios as a way to characterize frequency of states and probability of events occurring from time to time in the context of resilience evaluation. Hong et al. [14] use scenarios to simulate sustainability policy approaches for infrastructure projects. In summary, organizing spatial-temporalfunctional conditions into scenarios provides a basis for realistically framing all VRRS evaluations, enabling consideration of uncertainties for all conditions. The complementarity among the concepts suggests that scenarios are equally valuable to vulnerability, risk and sustainability, and consequently to VRRSability.

\subsubsection{Spatial, Temporal, Attribute Scale (g)}

Turner et al. [2] address scale for vulnerability at local, regional, national and international levels. Nyerges, Robkin and Moore [67] recognize the importance of scale in treating vulnerability and risk, since stressors and receptors must be characterized in terms of level of granularity. Miller et al. [55] describe the importance of why methodology, resilience, and vulnerability researchers need to work together on common case studies, at multiple spatial scales so that comprehensive findings develop. Gotham and Campanella [96] coupled vulnerability and resilience to examine dynamics of interaction across scales. Romero-Lankao and Dodman [84] examine interactions between urbanization and outcomes of global environmental change using vulnerability and resilience perspectives, showing how specific governance mechanisms addressing systems at different scales shape the design and implementation of urban management responses. Characterizing socialecological systems scenarios using transition phases at different spatial-temporal scales can foster understanding of granularities; the overall framework articulated using biological principles forms a 'panarchy' to characterize resilience [82]. Specifying scales helps organize scenarios for articulating system identities for addressing resilience [66,97]. Scale is particularly important when considering sustainable transformations using a resilience perspective [93]. Yigitcanlar and Dur [98] develop sustainability assessment indicators at neighborhood, local, and regional scales, showing insights for each. Wu [99] describes why landscape and regional scales are pivotal for sustainability outcomes. Scale is important for environmental governance, when examining social-ecological systems through resilience thinking, while undertaking collaborative learning for sustainability [6]. In summary, multi-spatial-temporal scales are beneficial for framing scenarios when characterizing systems. Scale is thus an important consideration in all four concepts, and as such is equally important to VRRSability.

\subsubsection{Levels of Resolution for Units of Analysis (h)}

Aven [34,35] explores vulnerability, risk, and resilience using individual elements, suggesting that a systems approach is not necessary for all problems. However, others suggest that a systems focus is necessary for a holistic approach to complex systems problems [3,4]. Nelson et al. [100] and Miller et al. [55] argue that individual feature and system approaches are complementary, in the sense that actor-based analyses look at the processes of negotiation, decision making, and action, whereas systems-based analyses examine the interaction of social and ecological processes. Actor-based (agent-oriented) is more focused (detailed), and system-based is more holistic (synoptic, big picture). Sahely and Kennedy [59] articulate a sub-systems level of resolution as important for understanding water, energy, and chemicals as part of sustainable water systems. Blackmore and Plant [101] characterize integrated urban water systems using a sustainability management perspective that incorporates risk and resilience. They describe how risk assessment commonly focuses on the states of controls that operate on specific system components, plus the likelihood and consequences of control failure; whereas resilience addresses disturbances to system-as-a-whole behavior, which addresses the importance of differentiating levels of 
resolution for system elements. Lundin and Morrison [102] examined various resolutions for sustainable water quality indicators. Nyerges et al. [1] developed a geospatial representation framework that incorporates individual and systems units of analysis as a basis for characterizing sustainable systems challenges; both needed to represent a space-time dynamic of sustainable systems. In summary, the four concepts are complementarity when addressing unit of resolution; that is, VRRSability applies to all levels of units. Selection of scenarios in coordination with spatial-temporal scales frame choices about granularity (resolution) of elements and relationships, sub-systems, and systems; thus, all three levels are important for examining behaviors across scales.

\subsubsection{Feedback (i)}

A coupled systems perspective enhances opportunity for addressing feedback and system transformation [15,103]. Walker and Salt's [15] 'resilience thinking' approach involves identifying regime shifts that are possible, with feedback changes that determine the thresholds between regimes, and the attributes of the system that govern the controlling variables and strengths of the feedbacks that influence regime shifts. Regime shifts occur when variables interact in substantially different ways or at different levels because the 'affinities' among variables change to result in different equilibrium dynamics. Andries [104] explores control theory to frame integration of dynamic systems models to address challenges for the design of effective governance regimes offering policy feedback within highly uncertain natural resource systems. Berkes [6] describes the importance of considering people and environment together, as social (human) and ecological (biophysical) sub-systems link through mutual feedback, and are interdependent and co-evolutionary within a resilience context. In summary, feedback mechanisms associated with relationships, encourage and/or discourage systems (functional performance) behavior. The concept of feedback appears to be more salient within the resilience literature, and less so in the sustainability literature, but largely untreated in the vulnerability and risk literature. However, in the context of integrated complex systems, feedback is critical, and thus a significant consideration when addressing VRRSability.

\subsubsection{Alternate (and Possibly Irreversible) Stable States (j)}

Gunderson and Holling [82] describe panarchy as a trajectory along which a system progresses cyclically through four functional phases of growth, conservation, release, and reorganization. A transition from one state to the next shifts a system into an 'alternate stable state' from a perspective of resilience [15,81], and the next state by definition is an alternate stable state. This alternative stable state means that a change in feedback occurs as well, for better or worse depending on the desirability of the state based on stakeholder perspectives. Within catastrophe theory [60], small changes in state can result in dramatic changes in alternative state stability, thus making the sustainability of a system somewhat challenging to address. In summary, the concept of alternate stable state is a concept of importance to the resilience literature, but is not so prevalent in the vulnerability, risk and sustainability literature. However, complementarity among concepts suggests that alternate stable states can add insight to vulnerability, risk and sustainability when applied to the context of integrated systems.

\subsubsection{Social Learning about VRRS Conditions ( $\mathrm{k}$ )}

Tompkins and Adger [56] examine social learning, specifically in relation to the acceptance of strategies that build social-ecological resilience. Over the past decade, there has been a shift from output-directed to process-oriented research, seeking knowledge as co-produced by a plurality of actors (scientists, researchers, and policy and community stakeholders) through a social learning process [105]. Nyerges, Robkin and Moore [67] and Jankowski and Nyerges [31] provide an overview how GIS can be used for risk communication to effect social learning in small- and medium-sized groups. 
Miller et al. [55] recommend creating mechanisms for collective reflection and learning among researchers, policy makers, practitioners, and stakeholders to capture important lessons learned about vulnerability and resilience in medium to large-size groups. Jordan et al. [106] examined knowledge development within citizen-science participation programs, discovering that participants learned by participating, but did not gain substantial insight into overall scientific activity, mostly because they were not exposed to the overall research project goals. Goldstein [90] organizes researchers reporting on a variety of ways to conceptualize and implement collaborative resilience as both a social learning process and an outcome of collective engagement with social-ecological complexity. They see social learning as a way to organize the framing of topics that can redefine them as appropriate.

Social learning in small, medium and large-size group settings using geographic information systems (GIS) is an important approach to sharing insights about habitat redevelopment with regard to sustainability management [31]. Research needs to explore reflection and learning, and also help design appropriate networks, institutions, and governance structures [61]. Ostrom [87] reports how stakeholder communities, in contrast to government regulators, often develop as good an insight, if not better insight and understanding, stemming from social learning about how to maintain sustainability in resource-oriented social-ecological systems. Pahl-Wostl [107] describes triple-loop social learning as a process that questions and transforms values, norms, and world views underlying extant regimes in the context of sustainability. Wyborn et al. [108] suggest how a social learning approach involving conservation policy makers and practitioners can facilitate learning and adaptation in the context of complexity, transformational change and uncertainty, while at the same time offering a broader focus that extends beyond technical approaches to acknowledge the socio-political challenges inherent to adaptation. Berkes [6] views socially collaborative learning as an essential approach to operationalizing adaptive environmental governance in the 21st century. He sees collaborative learning as an approach whereby further research, experimentation, and application might make a difference for operationalizing adaptive governance, with a focus on institutions, at all scales to effect sustainability.

In summary, social empowerment has gained credence in all four literatures. However, recent advances in approaches for community resilience and sustainability would seem to offer contributions to vulnerability and risk. As such, social empowerment would be a necessary aspect when performing VRRSability evaluations.

\subsubsection{Knowledge Systems for Evaluating VRRS Conditions (1)}

GIS supports vulnerability and risk assessment within many domains [67], suggesting that such systems will provide insights over the long-term for many organizations. Knowledge systems for integrated and interconnected vulnerability and risk assessment are being developed [3,4]. Schultz and Smith [63] demonstrate how a Bayesian approach to resilience assessment can link with approaches to risk assessment. Cutter et al. [10] processed geospatial data and created indicators of community resilience for all counties across the US, based on a standard set of data available enabling cross-region comparisons. Lam et al. [86] demonstrate the use of geospatial information technology for resilience assessment of US Gulf Coast counties, outlining how to connect vulnerability and adaptation to assess resilience. Indicators characterizing sustainability of infrastructure using life cycle assessment provides insight about states of systems over the long-term [100]. Cash et al. [109] describe a need for knowledge systems in support of sustainable development, recognizing that efforts to mobilize science and technology for sustainability are more likely to be effective when they manage boundaries between knowledge and action in ways that simultaneously enhance the salience, credibility, and legitimacy of the information they produce. Vogel et al. [105] describe how sustainability stakeholders often have a different approach to coming to know about a topic than do researchers. Embracing participatory knowledge tools using GIS is important to providing different ways to elicit values and interests as part of sustainability management [13]. In summary, all four concepts are 
complementary and important for knowledge systems; no single concept offers sufficient insight to address the considerations of the others. Each adds a different additional perspective to evaluative conditions, and thus together offer a broad and deep perspective through VRRSability evaluation.

\subsubsection{Operational Implementation $(\mathrm{m})$}

Nyerges, Robkin and Moore [67] report on applications of GIS for vulnerability and risk assessment. A major step forward involves integrating vulnerability and risk components suggested by $[3,4,11]$. Cutter et al. [10] implement resilience assessment as a static indicator approach using GIS. Miller et al. [55] identify the need for translating complex conceptual insights into operational vulnerability and resilience assessment methodologies, guidelines, and procedures that are easily accessible to practitioners and decision makers. Improvements in collaboration between resilience and vulnerability researchers with policy actors and practitioners would enable cross-approach strengths to ensure integrated approaches for addressing complex relationships [55]. Mumby et al. [70] implements spatial-temporal resilience for coral reefs and refer to risk, but do not implement an integrated approach. Lam et al. [86] demonstrate the integration of vulnerability, adaptation and resilience for counties along the US Gulf Coast. Schultz and Smith [46] view resilience assessment as the converse of risk assessment. Turner [5] mentions the four V-R-R-S concepts, recognizing a common pivot issue in coupled human-environment (naturalhuman) systems, distinguishing between two other pivot issues, environmental services and the trade-offs of these services with human outcomes, but operational computing implementations do not yet exist. Bochinni et al. [22] address all four but do not provide operational insights about an integrated approach. Berkes [6] suggests that governance for sustainability requires multilevel, integrative, and interdisciplinary research and action, with attention to integrated social-ecological sub-systems. None of the literature reviewed implements all four VRRS components as an integrated approach. In summary, operationalization of VRRS evaluation modeling as a final step of VRRS assessment requires a conceptual synthesis of components. Vulnerability and risk have been operationalized for years in software systems. More recently, resilience has been gaining attention, offering an additional perspective on management action. Sustainability has been discussed, but has always been considered either too simple or too complex a concept to operationalize, but the context of functional performance over time should clarify this challenge. The complementarity of the concepts suggests that all four can add insight to VRRSability evaluation if it were to be made operational from the various perspectives.

\section{Discussion}

The four tiers of MOESIR components, together with the three levels of abstraction presented in Figure 1, outline the topics addressed and not addressed in this paper. There is insufficient space in this paper for a comprehensive presentation of all material needed to articulate and elucidate information about VRRSability software design in detail, that is, the logical and physical levels of instantiation. Herein, we focused on MOESIR Tier 2 at the conceptual level of VRRS, particularly the sub-concepts of V-R-R-S components. All four V-R-R-S concepts individually have withstood the test of time as fruitful foci for assessments of complex decision problems, each in their own way. Although many two-way, three-way, and four-way syntheses appear in the literature, none results in a comprehensive controlled vocabulary to form the basis for an overarching concept herein called VRRSability.

The content analysis of definitions resulted in a total of five sub-concepts. The synthesis definitions contained a range of three to five sub-concepts, wherein both vulnerability and risk contained three, resilience contained four and sustainability contained five. The content analysis of the research literature presenting one to four of the V-R-R-S concepts results in thirteen sub-concepts, i.e., an additional eight sub-concepts added to the five identified through content analysis of definitions. The thirteen sub-concepts are listed in 
Table 2 in the order of information gain. That is, the earlier sub-concepts are essential as a foundation for the following ones, each in turn.

This content analysis is a necessary first step to identify foundational sub-concepts. Although we offer a next step for clarification, insights about conceptual relationships among VRRS concepts leading to robust decision support software design still require clarification. The result of a VRRSability synthesis acts as a controlled vocabulary for MOESIR Tier 2. This controlled vocabulary will provide the basis for assessments and designs within workflow(s) at Tier 3, i.e., a link between Tier 2 ontology and Tier 3 epistemology. The bridge between ontology and epistemology is seldom addressed, as mentioned earlier, but when addressed explicitly can lead to more robust software design.

Although this paper presents a synthesis of VRRS concepts that expand and deepen MOESIR Tier 2, a collection of robust relationships has yet to be presented; treating each concept separately, but in relation to one another, takes precedence over presenting the synthesis of relationships. Meanings of V-R-R-S as single concepts emerge across disciplinary knowledge domains, and are often seen as boundary objects, i.e., concepts that vaguely connect domains, but help to keep the domains separate based on interpretive flexibility [110]. Resilience, when viewed as a boundary object, contributes confusion to multiple interpretations within disciplinary knowledge domains [111]. Such concepts breed synergy and confusion at the same time. For example, vulnerability within natural hazards research commonly develops from a social perspective [37], while vulnerability within ecological (as well as climate change) research commonly develops from a biophysical perspective [37]. In contrast, some researchers explore 'bridging concepts', i.e., a way to span across domain boundaries to shed light on topics fostering integration of ideas through synthetic efforts. For example, sustainability [112] and resilience [113,114] are considered bridging concepts. As such, it behooves one to juxtapose the concepts to help clarify what each can contribute to the other within a human-environment (sustainable) systems perspective, and 'drill down' using specific characteristics to clarify relationships, e.g., as in a formal ontology specification. The more simplicity, hence clarity, we can find through synthesizing among V-R-R-S concepts, the easier it will be to devise a robust conceptual framework for elucidating relationships within complex systems.

As we move toward a conceptual framework, as depicted in the last row of Table

2, VRRSability is composed of 13 components. Using these components, we can characterize the essence of VRRSability as the following; Per enumerated conditions, system receptor(s) sensitivity(s) to (enumerated) stressor(s) with associated probabilities of occurrence and harm, given a probability of improvement to mitigate harmful disturbance for fostering short, medium and long-term health and/or well-being. The essence of vulnerability's contribution to VRRSability, characterized in terms of 8 components, includes receptor sensitivity to stressor(s). Risk is characterized by 10 components, wherein its essence of contribution to VRRSability involves a receptor probability of harm from stressor(s). Resilience is characterized by 12 components, wherein its essence of contribution to VRRSability includes a receptor system probability of improvement to a disturbance while maintaining function and feedback. Sustainability is characterized by 11 components, wherein the essence of its contribution to VRRSability includes short, medium and long-term well-being given various receptor and stressor conditions. From this enumeration of properties, no one V-R-R-S concept is a superset for all the concepts, hence the need for an overarching concept such as VRRSability.

Reducing confusion among conceptual components should foster communication between researchers and practitioners working on sustainable system research [38] and, in doing so, clarify terms to foster development of integrated software systems making use of these conceptual components. Although the method developed by Bocchini et al. [22] is useful, it is not general enough for systematically treating various kinds of complex systems because VRRS concepts appear as single concepts, without providing sub-component linkages that could form a synthesis across components. As such, we can describe the connections among adaptation, adaptive capacity, and transformation (change) in relation to VRRS concepts, and not as separate concepts within Tier 2. Suffice to say at this 
time, adaptation and adaptive capacity take on meaning as part of resilience. As such, transformation as the result of a management action occurs as part of response to resilience assessment, and occurs over a long and sustainable process.

In this research, we broadened the Tier 2 evaluation context as part of an assessment workflow to include risk, resilience, and sustainability, and thus seek to reduce confusion among VRRS conceptual components as we provide comprehensive insights about decision support for functional performance of complex sustainable systems. With this synthesis, VRRSability conceptual components in combination become more suited as a foundation for logical modeling of complex systems (as per Figure 1 abstraction layers); e.g., humanenvironment and/or natural-built interconnected infrastructure systems such as natural and built storm-water systems that influence water quality and quantity within urbanregional communities, as well. Case studies will require elucidation of concepts at Tiers 3 and 4 to make them practically useful; however, there is insufficient space in this manuscript to take up examples, but we will take this up in follow-on research.

Nonetheless, despite the absence of example case studies, based on the VRRSability analysis and synthesis, we observe that each conceptual component has one or more significant relationships with another concept when considering a systems context. We conclude that vulnerability is a part of risk, but sensitivity (for vulnerability) and probability of damage (for risk) are still important concepts, which differentiate them. Risk and resilience are complements of one another, wherein risk commonly involves evaluation of damages and resilience evaluation is about improvements that address disruptions. Resilience focuses on processes (linking states at fine granularity), while considering thresholds as tipping points, which bound alternative stable states. Sustainability focuses on coarser states (conditions) of performance-level outcomes motivated by diverse goals and objectives, while considering long-term contexts. Interestingly, evaluation of functional performance is important in all scenario conditions, and there is no reason to distinguish resilience from sustainability based upon the granularity or severity of conditions. It is a misleading distinction, as there is more advantage in differentiating them by diverse and long-term considerations from a sustainability perspective together with agility capacity from a resilience perspective. Although Redman [91] makes a good point about resilience being more about actions and sustainability more about outcomes, that distinction also can be limiting as short-term resilient and sustainable actions as well as long-term resilient and sustainable outcomes are important.

The VRRS literature review found that resilience of functional performance over time, and in association with diverse circumstances, was the most encompassing of VRRS concepts, and for this reason perhaps the last of the four concepts to be made operational. However, the literature review also found that sustainability has not been sufficiently synthesized and, as a result, has slowed progress toward an operational synthesis of vulnerability, risk, and resilience. Although resilience and sustainability are the most encompassing concepts, there is still reason to treat all four VRRS concepts within an evaluation of system functional performance; each conceptual component brings something different to the evaluative perspective. Vulnerability adds a perspective about threats to maintaining functional performance, while considering sensitivity of a receptor threatened by a stressor. Risk adds a perspective about the probability of harm and resulting damage to functional performance at a particular level, while considering (vulnerability) sensitivity. Resilience adds a perspective about capacity to withstand and/or improve the functional performance in the context of diverse scenario conditions; sensitivity is not often treated, but should be. Interestingly, sustainability as maintaining functional performance is at the core of conditions, while sustainability as a long-term (multi-generation) timeframe and sustainability as a diversity of receptors is a broad-based perspective that encompasses most problems. However, vulnerability, risk and resilience are mid-level and more focused concepts, and, when wedded with sustainability, provide added perspectives that can enhance sustainability evaluation for complex systems, particularly under varying conditions that could improve operational characterization. Synthesizing among the four concepts 
improves our understanding of each separately, and can eliminate some of the confusion among stakeholder communities 'talking past one another'.

\section{Conclusions about Next Steps for Operationalizing VRRSability}

A broad and deep knowledge gap has existed for decades when it comes to comparing the elements of V-R-R-S. Although the concepts of systems sustainability [1] and systems vulnerability [28] were used in previous research, we recognized a need for an overarching, i.e., more comprehensive, and yet simpler concept for decision evaluations situated at MOESIR Tier 2. Consequently, this paper demonstrates a deliberate effort to fill a decadesold knowledge gap by synthesizing the four V-R-R-S concepts into an overarching concept called VRRSability. However, the gap is only partially filled at this time.

This research is a stepping stone on the path toward the development of an operational computing framework for VRRSability in software. Translating concepts from a conceptual level of abstraction, which focuses on meaning of terms, into a logical level, which focuses on the relationships between and among terms, involves selecting a programming language that can comprehensively and consistently embrace the core of the concepts in terms of commensurate meaning. The easiest way to proceed with this translation is to specify units of measurement as well as the relationships between and among them to make sure units of measurement are commensurate. Before translating concepts to units of measurement, it is clear that outlining concepts in terms of sub-concept meaning is necessary to unpack the meaning of each concept, and is needed for a next step of comparison and contrast. The two-step approach to content analysis, based on definitions and literature review, served that purpose well. Although the relationships between and among sub-concepts have been enumerated fully, they are not presented herein. Some readers might ask why not include that level of detail in this paper? The authors originally considered this approach, but, after having tried it, it became clear the topic was too complex to be presented in the space available. Figure 1 reveals the trade-off dilemma. Making space for the report of the development process would require removing a considerable portion of the original synthesis report. Removing such material obfuscates the original intent of a comprehensive and transparent synthesis as would be expected in open systems literature. Several other papers presenting portions of a synthesis can be criticized for such an approach, and thus motivated the more comprehensive approach to synthesis reported in the present work.

Follow-on research to the results reported herein shall synthesize among concepts plus conceptual relations, based on comparison and contrast of several frameworks for devising a VRRSability conceptual framework. Creating a robust conceptual framework is thus a next step toward an operational computing framework. Such a multi-step approach to devising an operational computing framework offers an open and transparent approach to the intellectual synthesis supporting computational V-R-R-S. The multiple steps reported herein should assist other researchers with avoiding duplication in their V-R-R-S syntheses. We hope that this approach encourages better progress toward open software development, particularly for software systems directed at addressing complex societal decision problems.

Author Contributions: Conceptualization, Timothy Nyerges and Keith M. Reynolds; Methodology, Timothy Nyerges, John A. Gallo, and Steven D. Prager; Validation, Steven D. Prager; Formal Analysis, Timothy Nyerges; Resources, Timothy Nyerges and Steven D. Prager; Writing-Original Draft Preparation, Timothy Nyerges and John A. Gallo; Writing-Review and Editing, Philip J. Murphy, WenWen Li, Keith M. Reynolds, Steven D. Prager; Coordination, Timothy Nyerges. All authors have read and agreed to the published version of the manuscript.

Funding: This research received no external funding.

Data Availability Statement: All data appears in Appendix A and the respective literature cited.

Acknowledgments: Thank you to the editorial staff and reviewers for their contributions. Thank you to members of the Spatial Decision Support Consortium for their encouragement in pursuing the research. 
Conflicts of Interest: The authors declare no conflict of interest.

Disclaimer: The use of trade or firm names in this publication is for reader information and does not imply endorsement by the U.S. Department of Agriculture of any product or service.

\section{Appendix A}

Professionally credible glossaries published within domains of interest were consulted to identify vulnerability, risk, resilience and sustainability/sustainable development (VR-R-S) definitions. Definitions contain phrases that are parsed to identify sub-concepts. An iterative process wherein all definitions and all sub-concepts within them were parsed before a final collection of sub-concepts was identified for each definition. Sub-concepts are labeled a to e across all four concepts using an information gain perspective. That is, within systems composed of elements and relations, one identifies stressor-receptor (systems) elements (label a) of concern before knowing functional relations, exposure pathways, or influence pathways (label b) among elements, a level of magnitude that identifies a dose (label c), a potential management (response-coping-adaptation) action (label d), and the resulting outcome/effect (label e). Labels were color coded to help distinguish sub-concepts as presented below.

a1: stressor and a2: receptor elements ; a: system
b: relation: exposure pathway ( structure, function performance, feedback)
c: dose-response thresholds ( for stressor to influence receptor )
d: response-coping (management action )
e: functional performance outcome effect

Appendix A.1. Vulnerability Definitions

Vulnerability from US EPA Risk Assessment Glossary (2014) $(a, b)$

Differences in risk resulting from the combination of both intrinsic differences [of receptor] (a2) in susceptibility (b) and extrinsic social stress factors such as low socioeconomic status, crime and violence, lack of community resources, crowding, access

to health care, education, poverty, segregation, geography ( a1 ), etc.

https://sor.epa.gov/sor_internet/registry/termreg/searchandretrieve/glossariesand keywordlists $/$ search.do?details=\&vocabName=Risk\%20Assessment $\% 20$ Glossary (accessed on 7 March 2021)

Vulnerability from USFS Risk Terminology Primer: Basic Principles and a Glossary for the Wildland Fire Management Community (2016), (a,b)

Potential exposure ( $\mathrm{b}$ ) of a receptor ( $\mathrm{a} 2$ ) to a stressor ( a1 ).

The physical feature (a1) or attribute (a1) that renders values (a2) susceptible (b) to a given hazard ( a1 ).

https:/ / www.fs.fed.us/rm/pubs/rmrs_gtr349.pdf (accessed on 2 July 2019)

Vulnerability from United Nations Handbook for UNISDR Terminology on Disaster Risk Reduction (2009), (a,b,e).

The characteristics and circumstances of a community, system or asset (a2 ) that make it susceptible to (b) the damaging effects (e ) of a hazard ( a1 ).

http://www.unisdr.org/files/7817_UNISDRTerminologyEnglish.pdf (accessed on 2 July 2019)

Vulnerability from IPCC Managing the Risks of Extreme Events (2012), (a,b,e).

The [ receptor ( a2 )] propensity or predisposition to be (b) adversely affected (e ).

https://www.ipcc.ch/pdf/special-reports/srex/SREX_Full_Report.pdf (accessed on 2 July 2019)

Vulnerability not included in definitions available from Resilience Alliance Glossary. 
http:/ / www.resalliance.org/glossary (accessed on 2 July 2019)

Appendix A.2. Risk Definitions

Risk from US EPA Environmental Management System Glossary (2011) (a,b,e).

The probability that something undesirable will happen (e) from exposure (b) to a hazard ( a1 ). Glossary of terms for the EMS which is in conformance with Executive Order 13423, Strengthening Federal Environmental, Energy, and Transportation Management.

https://sor.epa.gov/sor_internet/registry/termreg/searchandretrieve/glossariesand keywordlists $/$ search.do?details=\&vocabName=Risk\%20Assessment $\% 20$ Glossary (accessed on 7 March 2021)

Risk Terminology Primer: Basic Principles and a Glossary for the Wildland Fire Management Community (2016), p. 9, USFS Rocky Mountain Research Station Risk Glossary, $(\mathrm{a}, \mathrm{e})$.

Measure of the probability and consequence (e) of uncertain future events ( a1 ). https://www.fs.fed.us/rm/pubs/rmrs_gtr349.pdf (accessed on 2 July 2019)

Disaster risk from UN Glossary of Disaster Risk Reduction (2009), (a,b,e).

Combination (b) of the probability of an event ( a1 ) and its negative consequences e).

http:/ / www.unisdr.org/files/7817_UNISDRTerminologyEnglish.pdf (accessed on 2 July 2019)

Disaster risk from IPCC Managing the Risks of Extreme Events (2012), (a,b,c,d,e)

The likelihood over a specified time period of severe alterations in the normal functioning (b2) of a community or a society (a2) due to hazardous physical events (a1) interacting (b) with vulnerable social conditions (c), leading to widespread

\begin{tabular}{l} 
adverse human, material, economic, or environmental effects (e) that require \\
\hline immediate emergency response (d) to satisfy critical human needs \\
(c) and that may
\end{tabular}

https://www.ipcc.ch/pdf/special-reports/srex/SREX_Full_Report.pdf (accessed on 2 July 2019)

Risk concept is not offered in the Resilience Alliance glossary.

http:/ / www.resalliance.org/glossary (accessed on 2 July 2019)

Appendix A.3. Resilience Definitions

Resilience within Walker and Salt [15] (a,b,d).

From a perspective of sustainable development and social-ecological systems, " ... resilience is the capacity (d) of a system (a ) to absorb (d) disturbance (a1), undergo change (b ), and still retain essentially the same function (b2), structure (b1) and feedbacks, (b3)".

Walker and Salt [15] p. 3

Resilience within a UN Glossary of Disaster Risk Reduction (2009), (a,b,d,e).

From an emergency management perspective, resilience is defined as ... "The

of a system, community or society ( ab ) exposed (b ) to stressors ( a1 ) to resist, absorb, accommodate to and recover (d) from the effects (e ) of a stressor (a1 ) in a timely and efficient manner, including through the preservation and restoration (d) of its essential basic structures ( b1 ) and functions (b2)".

http:/ / www.unisdr.org/files/7817_UNISDRTerminologyEnglish.pdf (accessed on 2 July 2019)

Resilience within an IPCC Report, $(\mathrm{a}, \mathrm{b}, \mathrm{d}, \mathrm{e})$. 
From a global climate change perspective, resilience is defined as ... "The

of a system and its component parts (a ) to anticipate, absorb, accommodate, or recover from ( $d$ ) the effects of a hazardous event in a timely and efficient manner (e ), including through ensuring the preservation, restoration, or improvement (d) of its essential basic structures (b1) and functions ( b2 )".

https://www.ipcc.ch/pdf/special-reports/srex/SREX_Full_Report.pdf (accessed on 2 July 2019)

Resilience within an EPA Environmental System Management Glossary (2011), (b,c,d). Ability to adapt (d) to changing conditions (c) and prepare for, withstand, and rapidly recover from disruption $(\mathrm{b})$.

https://sor.epa.gov/sor_internet/registry/termreg/searchandretrieve/glossariesand keywordlists / search.do?details=\&vocabName=Risk\%20Assessment $\% 20$ Glossary $($ accessed on 7 March 2021)

Resilience within the Resilience Alliance glossary, (a,b,c,d,e)

the capacity (d) of a system ( a ) to absorb (d) disturbance (c ) and reorganize while undergoing change (e so as to still retain essentially the same function (b1), structure (b2), identity (b3), and feedbacks (b4 ).

https:/ / www.resalliance.org/glossary (accessed on 2 July 2019)

Appendix A.4. Sustainability Definitions

Sustainability within an EPA Emergency Management Systems Handbook (2011), $(\mathrm{a}, \mathrm{b}, \mathrm{d}, \mathrm{e})$.

Meeting the needs (c) of the present ( a2) without compromising (b) the ability (d ) of future generations to meet their needs ( e ).

https:/ / sor.epa.gov/sor_internet/registry/termreg/searchandretrieve/glossariesand keywordlists $/$ search.do?details=\&vocabName=Risk $\% 20$ Assessment $\% 20$ Glossary (accessed on 7 March 2021)

Sustainability within an American Society of Civil Engineering web site, (a,c,d,e).

A set of environmental, economic, and social conditions (a )- the "Triple Bottom Line" - in which all of society ( a ) has the capacity and opportunity to maintain and improve (d) its quality of life (a ) indefinitely, without degrading (c ) the quantity,
quality or the availability of natural, economic, and social resources (e ).

http:/ /www.asce.org/sustainability/ (accessed on 2 July 2019)

Sustainability within the Resilience Alliance website glossary, (d).

The capacity to create, test, and maintain adaptive capability (d).

http://www.resalliance.org/glossary (accessed on 2 July 2019)

Further Information: Holling, C.S. 2001. Understanding the complexity of economic, ecological, and social systems. Ecosystems 4: 390-405.

Sustainable development within a Resilience Alliance website glossary (a,c,d,e), no definition of sustainability per se.

The goal (e of sustainable development is to create (d) and maintain (c) prosperous (e social, economic, and ecological systems (a ).

http://www.resalliance.org/glossary (accessed on 2 July 2019)

Further Information: C., S. Carpenter, T. Elmqvist, L. Gunderson, C.S. Holling, and B. Walker. 2002. Resilience and sustainable development: Building adaptive capacity in a world of transformations. Ambio 31:437-440.

Sustainable development within UN Glossary of Disaster Risk Reduction (2009), $(a, b, c, d, e)$, no definition of sustainability per se. 
Development (b) that meets the needs ( c ) of the present [generations ( a2 )] without compromising ( b ) the ability (d) of future generations ( a2 ) to meet their own needs (e).

http:/ / www.unisdr.org/files/7817_UNISDRTerminologyEnglish.pdf (accessed on 2 July 2019)

Sustainable development within an IPCC Managing the Risks of Extreme Events (2012), (a,b,d,e), no definition of sustainability per se.

Development (b) that meets the needs (c) of the present [generations ( a2)] without compromising ( b ) the ability (d) of future generations ( a2 ) to meet their own needs (e).

https://www.ipcc.ch/pdf/special-reports/srex/SREX_Full_Report.pdf (accessed on 2 July 2019)

\section{References}

1. Nyerges, T.; Roderick, M.; Prager, S.; Bennett, D.; Lam, N. Foundations of sustainability information representation theory: Spatial-temporal dynamics of sustainable systems. Int. J. Geographical Inf. Sci. 2014, 28, 1165-1185. [CrossRef]

2. Turner, B.L., II; Kasperson, R.E.; Matson, P.A.; McCarthy, J.J.; Corell, R.W.; Christensen, L.; Eckley, N.; Kasperson, J.X.; Luers, A.; Martello, M.L.; et al. A framework for vulnerability analysis in sustainability science. Proc. Natl. Acad. Sci. USA 2003, 100, 8074-8079. [CrossRef] [PubMed]

3. Haimes, Y. On the Definition of Resilience in Systems. Risk Anal. 2009, 29, 498-501. [CrossRef]

4. Haimes, Y. On the Complex Definition of Risk: A Systems-Based Approach. Risk Anal. 2009, 29, 1647-1654. [CrossRef]

5. Turner, B.L., II. Vulnerability and Resilience: Coalescing or Parallel Approaches for Sustainability Science? Global Environ. Chang. 2010, 20, 570-576. [CrossRef]

6. Berkes, F. Environmental Governance for the Anthropocene? Social-Ecological Systems. Resilience 2017, and Collaborative Learning. Sustainability 2010, 9, 1229. [CrossRef]

7. Li, Y.; Lin, J.; Li, Y.; Nyerges, T. Developing a Resilience Assessment Framework for the Urban Land-Water System. J. Land Degrad. Dev. 2019, 30, 1107-1120. [CrossRef]

8. Liu, X.; Ferrario, E.; Zio, E. Resilience Analysis Framework for Interconnected Critical Infrastructures. ASCE-ASME Part B: Mechanical Engineering. J. Risk Uncertain. Eng. Syst. 2017, 17. [CrossRef]

9. Le Gauffre, P.; Joannis, C.; Vasconcelos, E.; Breysse, D. Performance Indicators and Multi-criteria Decision Support for Sewer Asset Management. J. Infrastruct. Syst. 2007, 13. [CrossRef]

10. Cutter, S.; Barnes, L.; Berry, N.; Burton, C.; Evans, E.; Tate, E.; Webb, J. A place-based model for understanding community resilience to natural disasters. Global Environ. Chang. 2008, 18, 598-606. Available online: https://www.sciencedirect.com/ science/article/abs/pii/S0959378008000666 (accessed on 7 July 2019). [CrossRef]

11. Barker, K.; Haimes, Y. Uncertainty analysis of interdependencies in dynamic infrastructure recovery: Applications in risk-based decision-making. J. Infrastruct. Syst. 2009, 15, 394-405. [CrossRef]

12. Minsker, B.; Baldwin, L.; Crittenden, J.; Kabbes, K.; Karamouz, M.; Lansey, K.; Malinnowski, P.; Nzewi, E.; Pandit, A.; Parker, J.; et al. Progress and Recommendations for Advancing Performance-Based Sustainable and Resilient Infrastructure Design. J. Water Resour. Plan. Manag. 2015, 141. [CrossRef]

13. Nyerges, T.; Jankowski, P. Regional and Urban GIS: A Decision Support Approach; Guilford: New York, NY, USA, 2010.

14. Hong, Y.; Liyina, S.; Yongtaoa, T.; Jianlib, H. Simulating the Impacts of Policy Scenarios on the Sustainability Performance of Infrastructure Projects. Autom. Constr. 2011, 20, 1060-1069. Available online: https:/ /www.sciencedirect.com/science/article/ $\mathrm{pii} /$ S0926580511000562 (accessed on 12 January 2020).

15. Walker, B.H.; Salt, D. Resilience Practice: Building Capacity to Absorb Disturbance and Maintain; Island Press: Washington, DC, USA, 2010.

16. Mazumder, R.K.; Salman, A.M.; Li, Y.; Yu, X. Performance Evaluation of Water Distribution Systems and Asset Management. ASCE 2018, 24. [CrossRef]

17. Linkov, I.; Todd, B.; Felix, C.; Jennifer, D.; Cate, F.-L.; Wolfgang, K.; James, H.L.; Anders, L.; Benoit, M.; Jatin, N.; et al. Miranda Schreurs and Thomas Thiel-Clemen 2014, Changing the resilience paradigm. Nat. Clim. Chang 2014, 4, 407-409. [CrossRef]

18. Costanza, R.; d'Arge, R.; de Groot, R.; Farberk, S.; Grasso, M.; Hannon, B.; Limburg, K.; Naeem, S.; O’Neill, R.; Paruelo, J.; et al. The value of the world's ecosystem services and natural capital. Nature 1997, 387, 15. [CrossRef]

19. Stanley, S.; Grigsby, S.; Booth, D.; Hartley, D.; Horner, R.; Hruby, T.; Thomas, J.; Bissonnette, P.; Fuerstenberg, R.; Lee, J.; et al. Puget Sound Characterization-Volume 1: The Water Resource Assessments (Water Flow and Water Quality). 2015. Available online: https: / fortress.wa.gov/ecy/publications/SummaryPages/1106016.html (accessed on 12 June 2018).

20. Ceskavich, R.; Sasani, M. Methodology for Evaluating Community Resilience. Nat. Hazards Rev. 2018, 19. [CrossRef] 
21. Linkov, I.; Fox-Lent, C.; Read, L.; Allen, C.R.; Arnott, J.C.; Bellini, E.; Coaffee, J.; Florin, M.-V.; Hatfield, K.; Hyde, I.; et al. Tiered Approach to Resilience Assessment. Risk Anal. 2018, 38, 1772-1780. [CrossRef]

22. Bocchini, P.; Frangopol, D.M.; Ummenhofer, T.; Zinke, T. Resilience and Sustainability of Civil Infrastructure: Toward a Unified Approach. J. Infrastruct. Syst. 2014, 20, 04014004. [CrossRef]

23. Guarino, N. Understanding, building and using ontologies. Int. J. Human-Computer Stud. 1997, 46, 293-310. [CrossRef]

24. Couclelis, H. Ontologies of geographic information. Int. J. Geogr. Inf. Sci. 2010, 24, 1785-1809. [CrossRef]

25. Li, N.; Raskin, R.; Goodchild, M.; Janowicz, K. An Ontology-Driven Framework and Web Portal for Spatial Decision Support1. Trans. GIS 2012, 16, 313-329. [CrossRef]

26. Couclelis, H. Ontology, Epistemology, Teleology: Triangulating Geographic Information Science. In Research Trends in Geographic Information science; Gerhard, N., Ed.; Springer: Berlin/Heidelberg, Germany, 2009; pp. 3-16.

27. E Sieber, R.; Haklay, M. The epistemology(s) of volunteered geographic information: A critique. Geo Geogr. Environ. 2015, 2, 122-136. [CrossRef]

28. Nyerges, T.; Ballal, H.; Steinitz, C.; Canfield, T.; Roderick, M.; Ritzman, J.; Thanatemaneeratt, W. Geodesign Dynamics for Sustainable Urban Watershed Development. Sustain. Cities Soc. 2016, 25, 13-24. [CrossRef]

29. Steinitz, C. A Framework for Geodesign: Changing Geography by Design; Esri Press: Redlands, CA, USA, 2012.

30. Malczewski, J. GIS and Multicriteria Decision Analysis; Wiley \& Sons: New York, NY, USA, 1999.

31. Jankowski, P.; Nyerges, T. GIS for Group Decision Making; Towards a Participatory Geographic Information Science; CRC Press: Boca Raton, FL, USA, 2001.

32. White, G.F. Natural Hazards; Oxford: New York, NY, USA, 1974.

33. Fineman, M.A. Vulnerability and Inevitable Inequality. Oslo Law Rev. 2017, 1, 133-149. [CrossRef]

34. Aven, T. On how to define, understand and describe risk. Reliab. Eng. Syst. Saf. 2010, 95, 623-631. [CrossRef]

35. Aven, T. On Some Recent Definitions and Analysis Frameworks for Risk, Vulnerability, and Resilience. Risk Anal. 2010, 31, 515-522. [CrossRef] [PubMed]

36. Holling, C.S. Resilience and Stability of Ecological Systems. Annu. Rev. Ecol. Syst. 1973, 4, 1-23. [CrossRef]

37. Adger, W.N. Social and ecological resilience: Are they related? Prog. Hum. Geogr. 2000, 24, 347-364. [CrossRef]

38. Manyena, S.B. The concept of resilience revisited. Disasters 2006, 30, 434-450. [CrossRef] [PubMed]

39. Alexander, D.E. Resilience and disaster risk reduction: An etymological journey. Nat. Hazards Earth Syst. Sci. 2013, 13, 2707-2716. [CrossRef]

40. Masten, A.S. Resilience in developing systems: The promise of integrated approaches. Eur. J. Dev. Psychol. 2016, 13, 297-312. [CrossRef]

41. Carlson, J.; Haffenden, R.; Bassett, G.; Buehring, W.; Collins, M.; Folga, S.; Haffenden, B.; Petit, F.; Phillips, J.; Verner, D.; et al. Resilience: Theory and Applications, Argonne National Laboratory, 2012. Available online: https://publications.anl.gov/ anlpubs/2012/02/72218.pdf (accessed on 8 March 2021).

42. Bruntland Commission. Report of the UN Commission on Environment and Development. 1987. Available online: https: // sustainabledevelopment.un.org/content/documents/5987our-common-future.pdf (accessed on 8 March 2021).

43. Kates, R.; Clark, W.C.; Al, E.; Hall, J.M.; Jaeger, C.; Lowe, I.; McCarthy, J.; Schellnhuber, H.J.; Bolin, B.; Dickson, N.M.; et al. Sustainability Science. SSRN Electron. J. 2000, 292, 641-642. [CrossRef]

44. Purvis, B.; Mao, Y.; Robinson, D. Three pillars of sustainability: In search of conceptual origins. Sustain. Sci. 2019, 14, 681-695. [CrossRef]

45. DeSanctis, G.; Poole, M.S. Capturing the Complexity in Advanced Technology Use: Adaptive Structuration Theory. Organ. Sci. 1994, 5, 121-147. [CrossRef]

46. Nyerges, T.L.; Jankowski, P. Enhanced Adaptive Structuration Theory: A theory of GIS-supported collaborative decision making. Geogr. Syst. 1997, 4, 225-259.

47. Poteet, A.M.; Janssen, M.A.; Ostrom, E. Working Together: Collective Action, the Commons, and Multiple Methods in Practice; Princeton University Press: Princeton, NJ, USA, 2010.

48. US EPA. Risk Assessment Glossary, 2010. Available online: https://ofmpub.epa.gov/sor_internet/registry/termreg/ searchandretrieve/glossariesandkeywordlists/search.do (accessed on 7 March 2021).

49. US Forest Service. Risk Terminology Primer: Basic Principles and a Glossary for the Wildland Fire Management Community. Available online: https:/ /www.fs.usda.gov/treesearch/pubs/50912 (accessed on 16 July 2019).

50. United Nations 2009. UN Handbook for UNISDR Terminology. Available online: https://www.unisdr.org/we/inform/ terminology (accessed on 16 July 2019).

51. IPCC-Intergovernmental Program on Climate Change 2012. Managing the Risks of Extreme Events and Disasters to Advance Climate Change Adaptation. Available online: https://www.ipcc.ch/report/managing-the-risks-of-extreme-events-and-disastersto-advance-climate-change-adaptation/ (accessed on 16 July 2019).

52. US EPA 2011. Environmental Management Systems Glossary. Available online: https://ofmpub.epa.gov/sor_internet/ registry/termreg/searchandretrieve/glossariesandkeywordlists/search.do?details=\&vocabName=EMS\%20Glossary (accessed on 7 March 2021).

53. Resilience Alliance (2019). Glossary. Available online: https:/ /www.resalliance.org/glossary (accessed on 16 July 2019). 
54. American Society of Civil Engineers (2019). Sustainability at ASCE. Available online: https:/ /www.asce.org/sustainability-atasce/ (accessed on 16 July 2019).

55. Miller, F.; Osbahr, H.; Boyd, E.; Thomalla, F.; Bharwani, S.; Ziervogel, G.; Walker, B.; Birkmann, J.; van der Leeuw, S.; Rockström, J.; et al. Resilience and vulnerability: Complementary or conflicting concepts? Ecol. Soc. 2010, 1511. Available online: https:/ / www.ecologyandsociety.org/vol15/iss3/art11/ (accessed on 3 March 2019). [CrossRef]

56. Tompkins, E.L.; Adger, W.N. Does Adaptive Management of Natural Resources Enhance Resilience to Climate Change? Ecol. Soc. 2004, 9. [CrossRef]

57. Luers, A.L. The surface of vulnerability: An analytical framework for examining environmental change. Glob. Environ. Chang. 2005, 15, 214-223. [CrossRef]

58. Haimes, Y.Y. On the Definition of Vulnerabilities in Measuring Risks to Infrastructures. Risk Anal. 2006, 26, 293-296. [CrossRef]

59. Sahely, H.R.; Kennedy, C.A. Water Use Model for Quantifying Environmental and Economic Sustainability Indicators. J. Water Resour. Plan. Manag. 2007, 133, 550-559. [CrossRef]

60. Prager, S.D.; Reiners, W.A. Historical and emerging practices in ecological topology. Ecol. Complex. 2009, 6, 160-171. [CrossRef]

61. Folke, C.; Carpenter, S.; Elmqvist, T.; Gunderson, L.; Holling, C.S.; Walker, B. Resilience and Sustainable Development: Building Adaptive Capacity in a World of Transformations. Ambio 2002, 31, 437-440. [CrossRef]

62. Bruneau, M.; Chang, S.E.; Eguchi, R.T.; Lee, G.C.; O’Rourke, T.D.; Reinhorn, A.M.; Shinozuka, M.; Tierney, K.; Wallace, W.A.; von Winterfeldt, D. A Framework to quantitatively assess and enhance the seismic resilience of communities. Earthq. Spectra 2003, 19, 733-752. [CrossRef]

63. Schultz, M.T.; Smith, E.R. Assessing the Resilience of Coastal Systems: A Probabilistic Approach. J. Coast. Res. 2016, 29, 1029-1050. [CrossRef]

64. Lounis, Z; McAllister, T.P. Risk-Based Decision Making for Sustainable and Resilient Infrastructure Systems. J. Struct. Eng. 2016, 142, 142. [CrossRef]

65. Carpenter, S.R.; Walker, B.L.E.; Anderies, J.M.; Abel, N. From Metaphor to Measurement: Resilience of What to What? Ecosyst. 2001, 4, 765-781. [CrossRef]

66. Cumming, G.S. Spatial Resilience in Social-Ecological Systems; Springer: London, UK, 2011.

67. Nyerges, T.; Robkin, M.; Moore, T.J. Geographic Information Systems for Risk Evaluation: Applications in Environmental Health. Cartogr. Geogr. Inf. Syst. 1997, 24, 123-144. [CrossRef]

68. Adger, W.N. Vulnerability. Glob. Environ. Chang. 2006, 16, 268-281. [CrossRef]

69. McLellan, B.; Zhang, Q.; Farzaneh, H.; Utama, N.A.; Ishihara, K.N. Resilience, Sustainability and Risk Management: A Focus on Energy. Challenges 2012, 3, 153-182. [CrossRef]

70. Mumby, P.J.; Wolff, N.H.; Bozec, Y.-M.; Chollett, I.; Halloran, P. Operationalizing the Resilience of Coral Reefs in an Era of Climate Change. Conserv. Lett. 2013, 7, 176-187. [CrossRef]

71. Cardona, O.D. The need for rethinking the concepts of vulnerability and risk from a holistic perspective: A necessary review and criticism for effective risk management. In Mapping Vulnerability: Disasters, Development and People; Bankoff, G., Frerks, G., Hilhorst, D., Eds.; Earthscan: London, UK, 2004; pp. 37-51.

72. Wisner, B.; Blaikie, P.; Cannon, T.; Davis, I. At Risk, Natural Hazards: People's Vulnerability and disasters; Routledge: London, UK, 2004.

73. Leh, M.; Bajwa, S.; Chaubey, I. Impact of land-use change on erosion risk: An integrated remote sensing, geographic information systems, and modeling methodology. Land Degrad. Dev. 2011, 24, 409-421. [CrossRef]

74. Rodriguez-Nikl, T. Linking disaster resilience and sustainability. Civ. Eng. Environ. Syst. 2015, 32, 157-169. [CrossRef]

75. Birkmann, J. Measuring vulnerability to promote disaster-resilient societies: Conceptual frameworks and definitions. In Measuring Vulnerability to Natural Hazards: Towards Disaster Resilient Societies; Birkmann, J., Ed.; United Nations University Press: Tokyo, Japan, 2006; pp. 9-54.

76. Birkmann, J. Risk and vulnerability indicators at different scales: Applicability, usefulness and policy implications. Environ. Hazards 2007, 7, 20-31. [CrossRef]

77. Eakin, H.; Luers, A.L. Assessing the Vulnerability of Social-Environmental Systems. Annu. Rev. Environ. Resour. 2006, 31, 365-394. [CrossRef]

78. Horan, R.D.; Fenichel, E.P.; Drury, K.L.S.; Lodge, D.M. Managing ecological thresholds in coupled environmental-human systems. Proc. Natl. Acad. Sci. USA 2011, 108, 7333-7338. [CrossRef] [PubMed]

79. Brooks, N. Vulnerability, Risk and Adaptation: A Conceptual Framework; Tyndall Centre for Climate Change Research: Norwich, UK, 2003; p. 21. Available online: https://www.researchgate.net/profile/Nick_Brooks2/publication/200029746_Vulnerability_Risk_ and_Adaptation_A_Conceptual_Framework/links/Ofcfd50ac169e15865000000.pdf (accessed on 6 January 2020).

80. Smit, B.; Wandel, J. Adaptation, Adaptive Capacity, and Vulnerability. Glob. Environ. Chang. 2006, 16, 282-292. [CrossRef]

81. $\mathrm{Ng}, \mathrm{A} . ;$ Loosemore, M. Risk allocation in the private provision of public infrastructure. Int. J. Proj. Manag. 2007, 25, 66-76. [CrossRef]

82. Walker, B.; Holling, C.S.; Carpenter, S.R.; Kinzig, A.P. Resilience, Adaptability and Transformability in Social-ecological Systems. Ecol. Soc. 2004, 9, 5. [CrossRef]

83. Gunderson, L.H.; Holling, C.S. (Eds.) Panarchy: Understanding Transformations in Human and Natural System; Island Press: Washington, DC, USA, 2002. 
84. Romero-Lankao, P.; Dodman, D. Cities in transition: Transforming urban centers from hotbeds of GHG emissions and vulnerability to seedbeds of sustainability and resilience. Curr. Opin. Environ. Sustain. 2011, 3, 113-120. [CrossRef]

85. Ganin, A.A.; Massaro, E.; Gutfraind, A.; Steen, N.; Keisler, J.M.; Kott, A.; Mangoubi, R.; Linkov, I. Operational resilience: Concepts, design and analysis. Sci. Rep. 2016, 6, 19540. [CrossRef] [PubMed]

86. Lam, N.S.N.; Reams, M.; Li, K.; Li, C.; Mata, L.P. Measuring Community Resilience to Coastal Hazards along the Northern Gulf of Mexico. Nat. Hazards Rev. 2016, 17, 04015013. [CrossRef]

87. Ostrom, E. A General Framework for Analyzing Sustainability of Social-Ecological Systems. Science 2009, 325, 419-422. [CrossRef] [PubMed]

88. Kasperson, R.E.; Renn, O.; Slovic, P.; Brown, H.S.; Emel, J.; Goble, R.; Kasperson, J.X.; Ratick, S. The Social Amplification of Risk: A Conceptual Framework. Risk Anal. 1988, 8, 177-187. [CrossRef]

89. Baker, S.M. Vulnerability and Resilience in Natural Disasters: A Marketing and Public Policy Perspective. J. Public Policy Mark. 2009, 28, 114-123. [CrossRef]

90. Goldstein, B. Collaborative Resilience: Moving Through Crisis to Opportunity; Massachusetts Institute of Technology: Cambridge, MA, USA, 2012.

91. Redman, C.L. Should Sustainability and Resilience Be Combined or Remain Distinct Pursuits? Ecol. Soc. 2014, 19, 37. [CrossRef]

92. Aguirre, R.; Nyerges, T. An Agent-Based Model of Participatory Decision Making for Sustainability Management. J. Artif. Soc. Soc. Simul. 2014, 177. Available online: http://jasss.soc.surrey.ac.uk/17/1/7.html (accessed on 12 March 2018).

93. Olsson, P.; Galaz, V.; Boonstra, W.J. Sustainability transformations: A resilience perspective. Ecol. Soc. 2014, 19. [CrossRef]

94. Swart, R.; Raskin, P.; Robinson, J. The problem of the future: Sustainability science and scenario analysis. Glob. Environ. Chang. 2004, 14, 137-146. [CrossRef]

95. Kjeldsen, T.R.; Rosbjerg, D. Choice of reliability, resilience and vulnerability estimators for risk assessments of water resources systems/Choix d'estimateurs de fiabilité, de résilience et de vulnérabilité pour les analyses de risque de systèmes de ressources en eau. Hydrol. Sci. J. 2004, 49. [CrossRef]

96. Gotham, K.F.; Campanella, R. Coupled Vulnerability and Resilience: The Dynamics of Cross-Scale Interactions in Post-Katrina New Orleans. Ecol. Soc. 2011, 16, 12. [CrossRef]

97. Cumming, G.S. Spatial resilience: Integrating landscape ecology, resilience, and sustainability. Landsc. Ecol. 2011, 26, 899-909. [CrossRef]

98. Yigitcanlar, T.; Dur, F. Developing a Sustainability Assessment Model: The Sustainable Infrastructure, Land-Use, Environment and Transport Model. Sustainability 2010, 2, 291-340. [CrossRef]

99. Wu, J. Landscape sustainability science: Ecosystem services and human well-being in changing landscapes. Landsc. Ecol. 2013, 28, 999-1023. [CrossRef]

100. Nelson, D.R.; Adger, W.N.; Brown, K. Adaptation to Environmental Change: Contributions of a Resilience Framework. Annu. Rev. Environ. Resour. 2007, 32, 395-419. [CrossRef]

101. Blackmore, J.M.; Plant, R.A.J. Risk and Resilience to Enhance Sustainability with Application to Urban Water Systems. J. Water Resour. Plan. Manag. 2008, 134, 224-233. [CrossRef]

102. Lundin, M.; Morrison, G.M. A life cycle assessment-based procedure for development of environmental sustainability indicators for urban water systems. Urban Water 2002, 4, 145-152. [CrossRef]

103. Walker, B.H.; Salt, D. Resilience thinking: Sustaining Ecosystems and People in a Changing World; Island Press: Washington, DC, USA, 2006.

104. Andries, J.M. Understanding the Dynamics of Sustainable Social-Ecological Systems: Human Behavior, Institutions, and Regulatory Feedback Networks. Bull. Math. Biol. 2015, 77, 259-280. [CrossRef] [PubMed]

105. Vogel, C.; Moser, S.C.; Kasperson, R.E.; Dabelko, G.D. Linking vulnerability, adaptation, and resilience science to practice: Pathways, players, and partnerships. Glob. Environ. Chang. 2007, 17, 349-364. [CrossRef]

106. Jordan, R.; Gray, S.; Howe, D.; Brooks, W.; Ehrenfeld, J. Knowledge Gain and Behavioral Change in Citizen-Science Programs. Conserv. Biol. 2011, 25, 1148-1154. [CrossRef] [PubMed]

107. Pahl-Wostl, C. A conceptual framework for analyzing adaptive capacity and multi-level learning processes in resource governance regimes. Global Environ. Chang. 2009, 19, 354-365. [CrossRef]

108. Wyborn, C.; van Kerkhoff, L.; Dunlop, M.; Dudley, N.; Guevara, O. Future oriented conservation: Knowledge governance. uncertainty and learning. Biodivers. Conserv. 2016, 25, 1401-1408. [CrossRef]

109. Cash, D.W.; Clark, W.C.; Alcock, F.; Dickson, N.M.; Eckley, N.; Guston, D.H.; Jäger, J.; Mitchell, R.B. Knowledge systems for sustainable development. Proc. Natl. Acad. Sci. USA 2003, 100, 8086-8091. [CrossRef] [PubMed]

110. Star, S.L. The Structure of Ill-Structured Solutions: Boundary Objects and Heterogeneous Distributed Problem Solving. In Distributed Artificial Intelligence Chapter 2; Gasser, L., Huhn, M.N., Eds.; Morgan-Kaufmann: San Francisco, CA, USA, 1989 ; pp. 37-54. [CrossRef]

111. Brand, F.S.; Jax, K. Focusing the Meaning(s) of Resilience: Resilience as a Descriptive Concept and a Boundary Object. Ecol. Soc. 2007, 12, 23. [CrossRef]

112. Paehlke, R. Sustainability as a Bridging Concept. Conserv. Biol. 2005, 19, 36-38. [CrossRef] 
113. Davoudi, S. Resilience: A Bridging Concept or a Dead End? Plan. Theory Pract. 2012, 13, 299-307. [CrossRef]

114. Baggio, J.A.; Brown, K.; Hellebrandt, D. Boundary object or bridging concept? A citation network analysis of resilience. Ecol. Soc. 2015, 20, 2. [CrossRef] 